AperTO - Archivio Istituzionale Open Access dell'Università di Torino

\title{
Pulling Effects in Immigrant Entrepreneurship: Does Gender Matter?
}

\section{This is the author's manuscript}

Original Citation:

Availability:

This version is available http://hdl.handle.net/2318/1828736

since 2022-07-06T15:31:44Z

Published version:

DOI:10.1080/00130095.2021.1874242

Terms of use:

Open Access

Anyone can freely access the full text of works made available as "Open Access". Works made available under a Creative Commons license can be used according to the terms and conditions of said license. Use of all other works requires consent of the right holder (author or publisher) if not exempted from copyright protection by the applicable law. 


\title{
Pulling Effects in Immigrant Entrepreneurship: Does Gender Matter?
}

\author{
Alessandra Colombellia ${ }^{\mathrm{a}, \mathrm{d}}$, Elena Grinza ${ }^{\mathrm{a}, *}$, Valentina Meliciani ${ }^{\mathrm{b}}$, Mariacristina Rossi ${ }^{\mathrm{c}, \mathrm{d}}$ \\ ${ }^{a}$ DIGEP, Politecnico di Torino - Turin \\ ${ }^{b}$ LUISS University - Rome \\ ${ }^{c}$ Department of Management, University of Turin - Turin \\ ${ }^{d}$ Collegio Carlo Alberto - Turin
}

\begin{abstract}
We examine whether the existing stock of immigrant firms induces more new firms of the same nationality in the same sector and province. We carry out the analysis by using Italian administrative data on the population of individual firms observed over the time window 2002-2013. We find support for a strong attractiveness (pulling) effect, which significantly differs by gender, with female immigrant entrepreneurs showing a lower reactiveness to the existing stock of firms compared to their male counterparts. Also, we find that exposure to gender inequality matters for the degree of equality of the pulling effect between genders. Only for countries of origin with unequal gender opportunities do female immigrants show a lower pulling effect than their male peers. No difference in the effect between men and women is, instead, found with reference to the degree of gender inequality in the destination. Keywords: Immigrant entrepreneurship, pulling effect, gender differences, gender inequality, country of origin, region of destination.

JEL: L26; J15; J16.
\end{abstract}

*Corresponding author. E-mail: elena.grinza@polito.it; phone: (0039) 0110904917. 


\section{Introduction}

Entrepreneurship is key to growth, by generating employment and innovation. The composition of firms differs by size, activity, and characteristics of the entrepreneurs. In many industrialized countries, immigrants are among the most active entrepreneurs (OECD, 2010b). Immigrants show a high propensity to entrepreneurship and have exploited opportunities for small businesses creation in many territories (OECD, 2010a) and sectors (Nathan, 2014, 2015). Although these businesses are sometimes low value-added activities, immigrant entrepreneurship is an important channel for promoting entry into the labour market and immigrants' integration in the territory of settlement. Moreover, it also contributes to the economic and social vitality of the host regions (Ndofor and Priem, 2011). In Italy, the ratio of immigrant entrepreneurs has shown an increasing pace over the last decade. The share of individual immigrant entrepreneurs has increased from $4 \%$ in 2002 (i.e. 123,266) to $8 \%$ in 2013 (i.e. 211,114). It is worth highlighting that the increasing trend of immigrant entrepreneurs has been in contrast to the substantial decrease in entrepreneurial activities in recent years due to the Great Recession. Therefore, immigrant entrepreneurship represents a strong and robust component of entrepreneurship in Italy. This is not surprising, considering that the Italian context is a favourable environment for immigrant entrepreneurship due to the prevalence of small and medium enterprises (SMEs), accounting for about $90 \%$ of the total number of firms, and to the presence of highly specialized local networks of production where immigrants can insert themselves more easily (a well-known example is the case of the Chinese community in the textile district of Prato).

Another dimension that has a different effect on shaping the labour force, and, particularly, entrepreneurship, is represented by women as entrepreneurs. Although men are more often entrepreneurs than women, the share of female entrepreneurs is rising constantly, also among immigrants (OECD, 2017). Self-employment is often a way to have more flexibility in working hours and arrangements. Therefore, it is often considered by women as more appealing than less flexible jobs. It can also be an effective alternative to unemployment. In this view, entrepreneurship can help females enhance their economic empowerment (OECD, 2014). This is particularly relevant for female immigrants, who are often among the weakest segments of the labour force (Fullin and Reyneri, 2010). On the other hand, women meet more constraints than men in starting up a business, which might intensify in the case of immigrants, especially those from less developed countries. For instance, women are less financially educated and ask and obtain less credit than men (Basiglio et al., 2019; Oggero et al., 2019). Italy is an interesting setting for analysing female immigrant entrepreneurship. First, Italy has an increasing trend in the number and share of females among entrepreneurs. The number of individual female entrepreneurs was 718,984 in 2002 and 762,065 in 2013, 
and this share has increased from $25 \%$ in 2002 to $29 \%$ in 2013 . The number and share of female immigrant entrepreneurs have also had a steady upward trend in recent years. While about $27 \%$ of individual immigrant entrepreneurs were females in 2002, in 2013, this percentage increased to about $32 \%$. The number of individual female immigrant entrepreneurs increased dramatically in recent years: from 33,656 in 2002 to as much as 66,371 in 2013. This evidence confirms the increasing significance of this phenomenon in Italy.

Understanding the channels and mechanisms favouring the creation of new firms by foreign-born individuals, and, especially, foreign-born women, in the host region is thus essential for promoting integration, well-being, and local vitality. Therefore, it is crucial to understand the dynamics of immigrant entrepreneurship and possible gender differences in this respect (Acs et al., 2011).

Although very little is known about the driving forces of immigrant entrepreneurship, recent studies suggest that sector-specific knowledge might be an important factor for new firm formation by immigrants. Kerr and Mandorff (2016) document this phenomenon in the United States, and explain it through a model of social interactions where non-work relationships facilitate the acquisition of sector-specific skills, which, in turn, can generate long-run occupational stratification. Tavassoli and Trippl (2019) investigate the impact of ethnic communities (ECs) on immigrants' entrepreneurship in Sweden and find that immigrants have a higher propensity to become entrepreneurs if they are located in ECs that have a high share of same-ethnic/same-sector entrepreneurs. They explain this as the outcome of ECs acting as providers of industry-specific institutional knowledge and by the 'role model' effect (Bosma et al., 2012; Chlosta et al., 2012; Krueger JR et al., 2000; Krumboltz et al., 1976; Van Auken et al., 2006a,b). ${ }^{1}$

Another relevant concept for studying immigrants' entrepreneurship is that of 'mixed embeddedness' (Jones et al., 2014; Kloosterman, 2010; Kloosterman et al., 1998, 1999; Price and Chacko, 2009). This concept refers to the embeddedness of immigrants in social networks of same-nationality communities and in the socio-economic and political-institutional environment of the territory of settlement. Embeddedness spurs entrepreneurship by giving access to social networks, providing capital, support, knowledge, and a supply or customer base (Tavassoli and Trippl, 2019). These networks are particularly important for immigrants to overcome the fact that they have less knowledge of local regulations, norms, routines, and culture compared to natives.

The present paper builds on the concepts of role model and mixed embeddedness to study

\footnotetext{
${ }^{1} \mathrm{~A}$ role model is a common reference to individuals who set themselves up as examples to be emulated by others, and who may stimulate or inspire other individuals to make certain (career) decisions and achieve certain goals (Bosma et al., 2012; Gibson, 2004).
} 
gender differences in the formation of new businesses by nationality of immigrants, sector, and province, drawing on Italian administrative data on the population of individual firms observed between 2002 and 2013 at the NUTS-3 regional level. After investigating whether the existing stock of immigrant firms induces more new firms of the same nationality in the same sector and province, we explore whether this pulling effect differs by gender and the main mechanisms behind the existence of gender differences in the effect.

This paper contributes to the literature in several ways. First, it contributes to the literature on the effects of immigrant networks on the creation of new firms by capturing an aggregate effect at the level of the immigrants' national group. Most importantly, this is the first paper that adds the gender dimension to the analysis by linking the literature on the determinants of immigrant entrepreneurship with studies on gender differences in the exploitation of social networks (Friebel et al., 2017; Lalanne and Seabright, 2011; Lindenlaub and Prummer, 2014). This literature builds on the notion of strong and weak links (Granovetter, 1973, 1974). It shows that women are more likely than men to engage in strong links (i.e. in close relationships) rather than in opportunistic ones (Baumeister and Sommer, 1997; Benenson, 1993; Booth, 1972; Moore, 1990), and that weak links favour more work-related outcomes compared to strong links. Based on this evidence, we argue that the determinants of the creation of new firms by immigrants can differ by gender, with men building more strongly on the existing networks. By adding the gender dimension, the analysis indicates whether there are gender differences in the extent of the pulling effect from community networks and whether the difference in this effect is driven by the degree of gender inequality in the country of origin and in the destination (region or province) of the immigrants.

We find strong and robust evidence that the existing stock of immigrant firms induces more new firms of the same nationality in the same sector and province and that this pulling effect is substantially higher for men than for women. We also find that gender differences are significant only for immigrants coming from countries with low levels of gender equality. Finally, the characteristics of the country of origin of the immigrants matter more than those of the destination in determining gender differences in the pulling effect.

The rest of this paper is structured as follows. Section 2 discusses the theoretical framework and introduces the working hypotheses. The data and the empirical methods are presented in Section 3 and Section 4, respectively. Section 5 presents and discusses the results. Conclusions and avenues for future research are discussed in Section 6. 


\section{Conceptual framework and hypotheses}

It is widely acknowledged that ethnic communities spur immigrant entrepreneurship (Andersson and Hammarstedt, 2015; Kloosterman et al., 1999; Light et al., 1993; Rodríguez-Pose and von Berlepsch, 2014; Tavassoli and Trippl, 2019). Although scholars have historically devoted scant attention to disentangling the different channels governing these dynamics, more recently, Tavassoli and Trippl (2019) have paved the way for a deeper understanding of the role played by ECs in the immigrants' decisions to become entrepreneurs.

The first mechanism lies in the knowledge spillovers from same-nationality immigrants. Immigrants are likely to know less about the host country's regulations, as well as about its norms, routines, and culture, compared to their native peers. This lack of knowledge can be compensated for by belonging to an immigrant community, which works as a device providing the necessary knowledge on how to get around the host country's institutional settings (Andersson and Larsson, 2016; Fritsch and Wyrwich, 2014; Guiso and Schivardi, 2011; Minniti, 2005). This argument is grounded in the mixed embeddedness approach, which stresses the relevance of immigrants' embeddedness in the social networks of same-nationality communities, on the one hand, and in the socio-economic and political-institutional context of the host region, on the other hand (Jones et al., 2014; Kloosterman, 2010; Kloosterman et al., 1998, 1999; Price and Chacko, 2009). Immigrants can also benefit from knowledge spillovers coming from same-nationality entrepreneurs employed in the same industry. Social networks of same-nationality communities exert a critical role in diffusing industry-specific information that relates to, for example, supply-chain or marketing channels and that is useful for the new business (Damm, 2009; Raijman and Tienda, 2000). These arguments about institutional and industry-specific knowledge spillovers within social networks of same-nationality communities stress the importance of the 'learning-by-support' mechanism (Bosma et al., 2012; Chlosta et al., 2012).

A further argument to explain the influence of same-nationality communities on immigrant entrepreneurship consists of the 'role model' effect (Bosma et al., 2012; Chlosta et al., 2012). It has been widely acknowledged that role models may strongly affect career choices (Krumboltz et al., 1976), including decisions to become an entrepreneur (Krueger JR et al., 2000; Van Auken et al., 2006a,b). Through learning-by-example mechanisms, individuals may learn new skills inspired by the observation of the role models with whom they can identify (Gibson, 2004). According to the role identification theory, however, the degree of similarity between the would-be entrepreneur and the role model matters. The extent to which the role model inspires the would-be entrepreneur depends upon the perceived compatibility between the behaviour of the role model and their own behavioural opportunities (Slack, 2005). Previous empirical analyses have provided support to this theory and have 
confirmed that entrepreneurs and their role models tend to be similar in terms of race (Hernandez, 1995; Maccoby and Jacklin, 1974; Ruef et al., 2003), nationality, gender (Andersson and Hammarstedt, 2011 ${ }^{2}$ ), and sector (Bosma et al., 2012). These dynamics also emerge at the regional level. Previous empirical work has shown that the regional variance in entrepreneurship can be explained by the availability of role models at the local level (Fornahl, 2003; Lafuente et al., 2007; Sternberg, 2009). The presence of entrepreneurs within a region may encourage new entrepreneurial activities as it is easier to find an appropriate example in close geographical proximity. Moreover, the existence of entrepreneurs nearby may legitimize entrepreneurial aspirations and actions (Davidsson and Wiklund, 1997; Mueller, 2006). ${ }^{3}$ According to this line of reasoning, we expect immigrants to be influenced by samenationality, same-industry, same-province entrepreneurs in their choice to start their own business. Characteristics like sector and nationality facilitate role identification of would-be entrepreneurs within a region.

Given these arguments, we test the following hypothesis:

Hypothesis 1: The higher the stock of immigrant entrepreneurs, the higher is the formation of new firms by the same-nationality group in the same sector and province.

Tavassoli and Trippl (2019), using individual-level data on immigrants in Sweden, find that an immigrant's decision to leave employment for entrepreneurship is positively affected by being located in a region with a large portion of 'same ethnics-same sector' immigrant entrepreneurs. We investigate whether a similar effect also applies at the level of the immigrants' national group (rather than at the individual level), thereby resulting in a pulling effect where new entrepreneurs of the same nationality are attracted in the same sector and province by the stock of existing immigrant entrepreneurs. Most importantly, our main contribution to the literature is to investigate gender differences in the pulling effect. In so doing, we build on the literature on gender differences in social networks and role models.

Documented empirical findings show that men's and women's social networks differ. Women tend to form networks that are more stable, path-dependent, and composed to a higher degree of strong rather than weak links. On the contrary, men are less selective and more opportunistic in their interpersonal behaviour, which leads them to develop networks with more new links and consisting of weaker ties. Early work by Granovetter $(1973,1974)$,

\footnotetext{
${ }^{2}$ The authors find that the father is the dominant role model among male immigrants, while female immigrants inherit general self-employment abilities from both parents.

${ }^{3}$ Wyrwich et al. (2019) analyse the impact of failing role models on the perception of entrepreneurship among non-entrepreneurs at the local level. They show that while observing successful entrepreneurs reduces the fear of failure, observing business failure increases it.
} 
which distinguishes between strong links (i.e. close relationships) and weak links (i.e. more casual and opportunistic acquaintanceships), argues that weak links are often more useful in contexts such as searching for a job, where the acquaintances' greater ability to provide novel information outweighs their lower motivation to provide support and help. However, in the case of start-ups, strong ties are important to secure crucial resources. Moreover, for start-ups pursuing radical innovations, strong ties are also beneficial in the process of discovering opportunities, because of their ability to exchange tacit knowledge and trusted feedback on the nature and viability of opportunities (Elfring and Hulsink, 2003).

Women also tend to build more informal networks within the sphere of their family and friends (Brush, 1992; Ibarra, 1992; Munch et al., 1997; Verheul et al., 2002), whereas, on the contrary, men rely on more formal networks that could be significant and useful sources of knowledge when starting a new business. These differences could have a significant impact on the entrepreneurial propensity and effectiveness of women's networks.

Men and women also differ in the use of social networks. Previous studies have shown that women entrepreneurs have fewer networks than their male counterparts (Aldrich, 1989; Cromie and Birley, 1992; Hanson and Blake, 2009; Munch et al., 1997). The main argument proposed by these studies is that women entrepreneurs were homemakers or held non-managerial positions before starting their entrepreneurial career and, therefore, their network is less extensive and developed. Furthermore, women entrepreneurs also spend less time networking since they face higher barriers to balancing family and work responsibilities than their male counterparts (Verheul et al., 2002). These differences in the use of social networks may thus negatively affect entrepreneurial activities by women.

Moreover, recent evidence supports the view that women and men leverage their networks differently (Beaman et al., 2018; Mengel, 2020) and obtain different work-related benefits because of different network structures (Lalanne and Seabright, 2011; Lindenlaub and Prummer, 2014). Differences in men's and women's social networks may, therefore, contribute to understanding gender differences in career outcomes and may complement existing explanations of the persistent gender gap in labour market outcomes (see Bertrand, 2011, for a recent survey). Besides social networks, research on gender and entrepreneurship has shown that women's attitudes towards entrepreneurship depend on a broader range of factors than men's, including factors related to the quality of life, and that the types of entrepreneurial opportunities pursued by women are in relatively lower-performing industries than those by men (e.g. retail, service, etc.), because of their expectations regarding the likelihood of success in higher-growth industries (Sullivan and Meek, 2012).

Finally, differences in men's and women's entrepreneurial propensity and behaviour can be explained by the 'role model' argument. A significant dimension of role identification, 
other than nationality and industry, as previously discussed, is gender. In line with the role identification theory, previous empirical analyses have indicated that entrepreneurs tend to be attracted and inspired by role models of the same gender (Bosma et al., 2012). In our perspective, this means that female (male) immigrant entrepreneurs may be a stimulus mainly for other immigrant women (men). Given the relative scarcity of female entrepreneurs, the gender gap in entrepreneurship may thus persist over time. In this vein, for example, Klyver and Grant (2010) show that gender differences in entrepreneurial networking and participation stem from the paucity of role models in women's social networks.

Given these arguments, we posit our second hypothesis as follows:

Hypothesis 2: The relation between the stock of immigrant entrepreneurs and the formation of new firms by the same-nationality group in the same sector and province is stronger for men than for women.

Previous work has shown that gender differences in entrepreneurship cannot be explained solely based on the level of economic development, but that socio-economic variables measuring human development also matter. Maniyalath and Narendran (2016), in their empirical analysis using Global Entrepreneurship Monitor (GEM) data for 61 countries, find that national human and gender development indexes affect female entrepreneurship rates. Gendered institutions may exert a substantial influence on women's decisions to start their own businesses (Elam and Terjesen, 2010; Pathak et al., 2013; Urbano and Alvarez, 2014). The explanation depends on two indexes of gender development: empowerment (measured by the proportion of parliamentary seats occupied by females and the proportion of adult females with at least secondary education), and economic status (expressed as labour market participation), which have proved to be crucial drivers of female entrepreneurship. In this vein, we argue that in gender-unequal communities, the intensity and type of networks differ between men and women. In accordance with the previous literature on social networks and 'role model' effects, we posit that less equal communities, where, by definition, female labour market participation and educational levels are low, are characterized by more informal and less intense networking activity by females. At the same time, low levels of empowerment and economic status within less equal communities can signal socio-cultural barriers and the paucity of role models within the community.

Given this discussion, we formulate the following hypothesis:

Hypothesis 3: Gender differences in the relations between the stock of immigrant entrepreneurs and the formation of new firms by the same-nationality group in the same sector and province are larger for immigrants coming from more gender-unequal countries. 
However, does the degree of gender inequality in the destination also matter? The literature on regional determinants of entrepreneurship (see Sternberg, 2009) has shown that entrepreneurial behaviour is deeply affected by the spatial context. Moreover, studies on cultural assimilation (see Norris and Inglehart, 2012, for a review) suggest that immigrants gradually absorb the values and norms that predominate in their host society. In this respect, Italy is characterized by strong cultural and economic differences between regions. The South's production system comprises more agricultural firms and fewer services than the North, making it more difficult for women to set up a firm. Moreover, socio-cultural factors in southern regions negatively affect women's attitudes toward work and entrepreneurship more than in the northern regions. These differences in the geographical areas of an immigrant's destination can influence a female immigrant's propensity to start a new business and the size of the pulling effect.

This discussion leads to our fourth hypothesis, which we spell out as follows:

Hypothesis 4: Gender differences in the relations between the stock of immigrant entrepreneurs and the formation of new firms of the same-nationality group in the same sector and province are larger for immigrants going to more gender-unequal regions in the destination country.

Finally, we ask whether gender inequality in the country of origin of the immigrant entrepreneur matters more or less than gender inequality in the destination. However, we have no a priori expectations in this respect. On the one hand, theories of cultural integration suggest that immigrants gradually absorb the norms and social values of the destination. On the contrary, theories of divergence suggest that distinctive norms and values are persistent and deep-rooted within ethnic communities and that immigrants are likely to carry their culture with them when they settle in another country (Sahin et al., 2007; Norris and Inglehart, 2012). In particular, Sahin et al. (2007) find significant differences in female entrepreneurship between various immigrant groups in the Netherlands, which they attribute to persistent cultural diversity. According to this view, the presence of sub-cultures within multicultural regions may deepen the divergence between minority and majority communities (Acemoglu and Robinson, 2006; Anderson, 1983).

\section{Data}

In our empirical analysis, we employ the ASIA archive, a data set provided yearly by the Italian statistical institute (ISTAT) since the early 2000s. The ASIA data set collects yearly information on the entire population of individual entrepreneurs in Italy. It presents basic 
information about such individuals, including their country of birth (using which we can identify immigrants) and gender, which are gathered through their fiscal codes, and the industry classification and province of activity. We are aware that dealing with data on individual entrepreneurs (i.e., very small firms) requires additional caution in interpretation, particularly for female entrepreneurs. The structure of individual firms can hide microbusiness activities that might be part-time or multi-sectoral, or fall off the 'radar' of statistical agencies.

We use the ASIA data for a period of 13 years, from 2002 to 2013.

Our analysis is based on the aggregation of such individual-level data at fine aggregation levels: industry, province, and country of origin (and gender, depending on the regression specifications). We define industry at the 2-digit level of the ATECO 2007 classification of economic sectors, resulting in about 50 different categories in our data. The geographical unit of analysis is the NUTS-3 region, which identifies the Italian provinces. This choice appears appropriate for our analysis since the focus on same-nationality communities calls for a rather narrow definition of region, but large enough to statistically represent a region of entrepreneurial activities (Audretsch and Lehmann, 2005). There are about 110 different provinces represented. There are about 170 countries of origin of immigrant entrepreneurs observed in our data, virtually all the countries of the world. This multidimensional aggregation results in many different cells, which constitute the units of our analysis. In the regressions that do not account for the dimension of gender, there are about 16,000 of these cells per year. This number does not quite double when we consider the dimension of gender, that is, when we consider separately male and female entrepreneurs in each same-country community, province, and industry. This indicates that in some of the cells there are only male immigrant entrepreneurs and no female immigrant entrepreneurs.

Our analysis of immigrant entrepreneurs overall is based on 210,363 observations. When we consider the gender dimension, we have 210,363 observations referring to male immigrant entrepreneurs and 139,111 referring to female immigrant entrepreneurs.

We complement the information from the ASIA data set with several other data sources. We first collect the information to construct the immigration rates by year, province, and country of origin, which we use as a control variable in our regressions, from detailed population statistics provided by the ISTAT.

We then obtain the Gender Inequality Indexes (GIIs) and percentages of women in parliament in the countries of origin from the United Nations Development Programme (UNDP) in 2010. The GIIs and the percentages of women in parliament serve as proxies for measuring the degree of gender inequality in the entrepreneurs' countries of origin. We will use these indicators to test our hypotheses that relate gender differences to levels of inequality 
in the country of origin (see Sections 4 and 5). The GIIs are indexes developed by the UNDP to measure gender inequality in each country of the world. These indexes provide a synthetic indicator of the degree of gender inequality in a given country and are constructed based on multiple key dimensions, including health outcomes for females, degree of female empowerment, and labour market outcomes of women. ${ }^{4}$

We collect the Gender Equality Indexes (GEIs) in the regions of destination from Amici and Stefani (2013), at the Bank of Italy. We will use the GEIs to explore how gender differences are influenced by the degree of gender inequality in the destination of the immigrant entrepreneurs (see Sections 4 and 5). GEIs are useful for this purpose because they provide synthetic indexes of the overall level of gender inequality in the destination. Moreover, they are constructed based on the method behind the UNDP's GIIs, thus providing a consistent and homogeneous proxy for the degree of gender inequality in the destination. The GEIs are provided at the NUTS-2 level, that is, for each of the 20 Italian administrative regions.

Before the econometric analysis, it is helpful to explore the critical variables descriptively. In the following, we provide several graphs and tables for this purpose.

In Figure 1, we show how the total number of entrepreneurs (including native entrepreneurs) evolved over our observation period. After a noticeable decrease in the stock of entrepreneurs between 2002 and 2004, from 2004, there was a constant upward trend up to the global economic crisis in 2008. In 2008, the total number of individual entrepreneurs was around 2.85 million. Since then, the number of entrepreneurs in Italy has substantially decreased. By 2013, there were around 150,000 fewer entrepreneurs than in 2008.

[Insert Figure 1 around here]

In Figure 2, we depict the evolution over time of female and immigrant entrepreneurs. The data show an increasing trend in the share of females among entrepreneurs (blue line). Females represented about $25 \%$ of individual entrepreneurs in 2002 , but by 2013 , they were about $29 \%$. Immigrant entrepreneurs have become a significant proportion of entrepreneurs in Italy, and their weight has increased continually over the years (red line). In 2013, they represented about $8 \%$ of the total number of entrepreneurs.

[Insert Figure 2 around here]

In Figure 3, we present other trends that focus on female immigrant entrepreneurship. There was a steady upward trend in the representation of female entrepreneurs also among immigrants (blue line). Whereas about $27 \%$ of immigrant entrepreneurs were females in

\footnotetext{
${ }^{4}$ See http://hdr.undp.org/en for a detailed description of how the GIIs are constructed.
} 
2002 , in 2013, this percentage increased to about $32 \%$, even more than among the overall entrepreneurial population (i.e. 29\%, see Figure 2). The red line instead shows the proportion of immigrants among female entrepreneurs. It underwent a constant increase, almost doubling in our observation period. While less than $5 \%$ of female entrepreneurs were immigrants in 2002, this percentage increased to about $9 \%$ by 2013 .

[Insert Figure 3 around here]

Figures 4-7 show some of the variables presented in the graphs just discussed but from a geographical perspective. They show how the total number of entrepreneurs (Figure 4), the share of female entrepreneurs (Figure 5), the share of immigrant entrepreneurs (Figure 6 ), and the share of immigrants among female entrepreneurs (Figure 7) were distributed by province in 2013. As these figures show, there is significant variability across the Italian provinces.

The North of Italy features the highest stocks of entrepreneurs, particularly in the province of Turin and in many provinces of Lombardy and Veneto. However, vast stocks of entrepreneurs are also present in important provinces of the Centre and South of Italy, particularly in the areas of Rome, Naples, Bari, and Palermo (Figure 4).

[Insert Figure 4 around here]

The provinces in the central regions of Italy, especially Emilia-Romagna, Tuscany, and Lazio, feature the highest presence of females among entrepreneurs. High representations of female entrepreneurs are also found in several provinces of Sardinia, whereas the South of Italy typically features the lowest proportions of female entrepreneurs, coherently with low levels of female labour market activity in those areas (Figure 5).

[Insert Figure 5 around here]

North-Central Italian regions, especially the region of Emilia-Romagna, have the highest concentration of immigrant entrepreneurs. High proportions of immigrants among entrepreneurs are also found in the provinces of Friuli-Venezia Giulia and the area of Rome. Conversely, immigrant entrepreneurs are typically less present in the provinces of the South of Italy, which is consistent with the lower immigration rates in such places (Figure 6).

[Insert Figure 6 around here]

Provinces featuring high representations of immigrants typically also display high concentrations of immigrants among the female entrepreneurs. Therefore, the provinces in the 
regions of Emilia-Romagna and Friuli-Venezia Giulia are those featuring the highest proportions of immigrants among female entrepreneurs (Figure 7). Immigrant entrepreneurs among females are few in the South of Italy, with percentages often ranging between $2 \%$ and $6 \%$.

[Insert Figure 7 around here]

Lastly, Table 1 presents the relevant summary statistics. It collects the variables that we use in our regressions (see Section 4). It includes both those that do not consider the dimension of gender (shown in the first panel) and those that differentiate by gender (the second panel refers to males, while the third panel refers to females). On average, in a given cell (i.e. a given province, industry, and country of origin), 0.629 new individual firms are established each year. The standard deviation is high (equal to 4.826), suggesting that the number of new immigrant individual firms established each year varies greatly, depending on the industry, province, and country of origin of the entrepreneur. The average stock of firms in the same-nationality community, same industry, and same province is much higher, equal to 8.051. As for new firms, this number has high variability (standard deviation equal to 37.874 ), pointing to substantial differences between the different cells. Similar pictures emerge when differentiating between males and females, but with females showing both a lower stock and a lower number of new immigrant entrepreneurs.

[Insert Table 1 around here]

\section{Empirical model}

In Section 2, we have outlined a set of hypotheses and research questions, which we will test and investigate empirically by using the ASIA data set in Section 5. Here, we present our empirical models and estimating regressions. Our aims are (i) to estimate the role of existing same-nationality entrepreneurs as a driver of the creation of new firms by immigrants, (ii) to assess whether there are gender differences in these dynamics, and (iii) to explore whether the degrees of gender inequality in the country of origin and the destination have a role in shaping gender differences.

To test our first hypothesis, we estimate through Ordinary Least Squares (OLS) estimations several specifications of the following linear regression:

$$
\text { NewFirms } s_{t, j, n, p}=\beta \text { Firms }_{t-2, j, n, p}+\gamma X_{t-2, j, n, p}+\epsilon_{t, j, n, p} .
$$

Our dependent variable, NewFirms $s_{t, j, n, p}$, denotes the number of new individual firms (in logarithms) that are created in year $t$, in sector of economic activity $j$, by entrepreneurs 
with nationality $n$, in province $p$. Our regressor of interest is $F i r m s_{t-2, j, n, p}$. It denotes the number of existing individual firms (in logarithms) in year $t-2$, in industry $j$, in province $p$, with entrepreneurs originating from country $n$. Hence, NewFirms $s_{t, j, n, p}$ denotes the number of new individual firms created in year $t$ in a given province, industry, by entrepreneurs originating from a given country, whereas Firm $s_{t-2, j, n, p}$ denotes the stock of same-category individual firms two years before (i.e. at $t-2$ ). Our interest lies in $\beta$. It measures the attractiveness effect that the existing stock of firms exercises on would-be entrepreneurs originating from the same country and in the same industry and province. The regressor of interest is lagged for at least two reasons. First, this is because inserting a contemporaneous stock (i.e. at $t$ ) would mechanically pick the creation of new firms at $t$, thereby not allowing a neat capture of the dynamics of the attraction. Second, this is to mitigate potential endogeneity concerns stemming from reverse causality. ${ }^{5}$

In our regressions, we insert (in sequential progression) a variety of different control variables $\left(X_{t-2, j, n, p}\right)$. They include an extensive set of dummy variables controlling for time, industry, province, and country of origin fixed effects. We also add time dummies interacted with industry, province, and country of origin dummies, thereby controlling for different time trends in the various industries, provinces, and nationalities. It is important to remove these fixed effects. They can potentially influence both the creation of new firms and the existing stock of firms from a given country and in a given industry and province, thereby biasing the results. For instance, some provinces might be more active in the promotion of immigrant entrepreneurship than others. Similarly, there might be some industries undergoing periods of expansion and others undergoing periods of contraction. Also, there might be booms in the inflows of immigrants from specific countries and in some specific years. All these situations might affect both the stock of immigrant firms and the creation of new immigrant firms from the same country and in the same province and sector, without any attractiveness-type effect being involved.

The vector $X_{t-2, j, n, p}$ also includes a variable collecting immigration rates by province and country of origin (at $t-2$ ). This variable allows controlling for the relative weights of immigrants from a given country in each province, which can substantially influence both

\footnotetext{
${ }^{5}$ While we have chosen a two-year lag for the regressor of interest (and the control variables), we have tested the robustness of our results to the use of one- and three-year lags. Moreover, despite the use of lagged regressors and the wide array of fixed effects that we include in our regressions (see below), we have also implemented an instrumental variable (IV) estimation based on the shift-share instrument proposed in Card (2001) to further control for endogeneity issues. These robustness checks are discussed in detail in Appendix A. Notably, the results are virtually insensitive to the choice of one- or three-year lags in the regressors and IV estimation.
} 
the formation of new firms and the stock of firms from that country and in that province. ${ }^{6}$ Lastly, we include a control for the overall stock of entrepreneurs in a given industry and province (at $t-2$ and in logarithms), both as such and distinguishing between native and immigrant (except those considered) entrepreneurs. This control is crucial in order to take into account specificities in culture/vocation toward entrepreneurship in a particular province and industry and the importance of immigrant entrepreneurs therein.

An example could be helpful in clarifying the definitions of the variables. Let us consider the cell formed by Romanian entrepreneurs in the province of Milan in the construction industry. The dependent variable in Equation (1) is the (logarithm of the) number of such immigrant entrepreneurs in that industry and province who started their business in a given year (i.e. this is a flow). The regressor of interest is the (logarithm of the) number of such immigrant entrepreneurs in that industry and province two years before (i.e. this is a stock). One control variable is the immigration rate by province and country of origin. In our example, it says how many Romanian immigrants (relative to the total population) were located in the province of Milan two years before. Another control variable is the (natural logarithm of the) number of entrepreneurs (except those considered) by industry and province. In our example, it denotes the number of entrepreneurs other than Romanian entrepreneurs who operate in the province of Milan in the construction industry two years before. Finally, two control variables split this number between native entrepreneurs and immigrant (other than Romanian) entrepreneurs.

The estimation of Equation (1) allows us to test our first hypothesis according to which a higher stock of immigrant entrepreneurs from a given country and in a given sector and province is associated with a higher firm formation from same-nationality entrepreneurs in the same sector and province. ${ }^{7}$ To test and explore the other hypotheses and research questions, we use OLS estimations of several regression models, which are all based upon Equation (1). This baseline equation is modified and adapted to our specific needs, for example, by splitting the sample and running separate regressions for males and females or by adding relevant interaction terms.

\footnotetext{
${ }^{6}$ Appendix A also presents results for a version of Equation (1) that allows for an interaction effect between the stock of immigrant entrepreneurs from a given country and in a given sector and province and the presence of immigrants from the same country in the same province. As highlighted by an anonymous referee, whom we thank, there might be, and, in fact, there is, a positive interaction effect between these two variables.

${ }^{7}$ An alternative to estimating Equation (1) with OLS could be estimating a non-linear count data model (i.e. with NewFirms $s_{t, j, n, p}$ expressed in integers) with count data estimation techniques, such as negative binomial regressions or Poisson regressions. In this paper, we opted for linear estimations as neither negative binomial regressions nor Poisson regressions could achieve convergence once dummies beyond basic year dummies were added to the model.
} 
To test our second hypothesis that the attractiveness effect is stronger for men than for women, we estimate the following set of equations:

$$
\text { NewMaleFirms } s_{t, j, n, p}=\beta_{m} \text { Firms }_{t-2, j, n, p}+\gamma X_{t-2, j, n, p}+\epsilon_{t, j, n, p}
$$

and

$$
\text { NewFemaleFirms } s_{t, j, n, p}=\beta_{f} \text { Firms }_{t-2, j, n, p}+\gamma X_{t-2, j, n, p}+\epsilon_{t, j, n, p} \text {. }
$$

The two dependent variables NewMaleFirms $s_{t, j, n, p}$ and NewFemaleFirms $s_{t, j, n, p}$ denote, respectively, the number of new firms created by male and female immigrants from a given country and in a given sector and province in year $t$. The two coefficients of interest, $\beta_{m}$ and $\beta_{f}$ capture the associations between such variables and the overall stock of same-nationality entrepreneurs in the same sector and province in year $t-2$. The difference between these two coefficients, therefore, represents the gender gap in the attractiveness effect.

We also explore whether males and females respond differently to the stock of same- and other-gender entrepreneurs by estimating the following set of equations:

$$
\begin{aligned}
& \text { NewMaleFirms }_{t, j, n, p}=\beta_{m m} \text { FirmsSameGender }_{t-2, j, n, p}+ \\
& +\beta_{m f} \text { FirmsOtherGender }_{t-2, j, n, p}+\gamma X_{t-2, j, n, p}+\epsilon_{t, j, n, p}
\end{aligned}
$$

and

$$
\begin{aligned}
& \text { NewFemaleFirms } \text { Fi,j,n }_{t, p}=\beta_{f f} \text { FirmsSameGender }_{t-2, j, n, p}+ \\
& +\beta_{\text {fm }} \text { FirmsOtherGender }_{t-2, j, n, p}+\gamma X_{t-2, j, n, p}+\epsilon_{t, j, n, p}
\end{aligned}
$$

For males, that is, Equation (4), FirmsSameGender ${ }_{t-2, j, n, p}$ and FirmsOtherGender $_{t-2, j, n, p}$ denote, respectively, the stocks of male and female immigrant entrepreneurs from the same country and in the same sector and province at $t-2$. Therefore, $\beta_{m m}$ and $\beta_{m f}$ capture the attractiveness effects for males stemming from the stock of male and female entrepreneurs, respectively. Correspondingly, $\beta_{f f}$ and $\beta_{f m}$ in Equation (5) capture the attractiveness effects for females stemming from female and male entrepreneurs, respectively. This analysis is relevant because it allows evaluating whether gender differences also emerge in the way the formation of new firms responds to same- versus other-gender stocks of entrepreneurs.

Hypotheses 3 and 4 relate gender gaps in the attractiveness effect to gender inequality in the country of origin (Hypothesis 3) and the destination (Hypothesis 4). They predict that gender gaps are more substantial for immigrants originating from more gender-unequal countries and for immigrants going to more gender-unequal destinations. To test Hypothesis 4, we will estimate Equations (2) and (3) (from which we obtain the gender difference in the 
attractiveness effect as $\beta_{m}-\beta_{f}$ ) separately for immigrants originating from countries with low and high gender inequality. This will provide us with estimates of the gender differences for entrepreneurs coming from less and more gender-unequal countries. As discussed in Section 3, the levels of gender inequality in the countries of origin are proxied by the GIIs and the percentages of women in parliament. We proceed similarly to test Hypothesis 5, and estimate Equations (2) and (3) separately for immigrant entrepreneurs located in less or more gender-unequal destinations. As described before, we proxy the degree of gender inequality in the destination by using GEIs. This will allow us to obtain estimated gender differences in less and more gender-unequal destinations. ${ }^{8}$

Finally, we will answer our research question pertaining to the relative contribution of gender inequality in the country of origin versus destination. To do this, we will estimate Equations (2) and (3) separately for the four possible combinations of the degree of inequality in the country of origin and the degree of inequality in the destination. ${ }^{9}$

\section{Results}

We now present the results obtained from the estimation of the regression models outlined above. We proceed by presenting the results for the estimation of Equation (1) relating to our first hypothesis. We then present the results from the estimation of Equations (2) and (3) - and Equations (4) and (5) - which test for the presence of gender differences in the attractiveness effects (Hypothesis 2). Finally, we present the estimation results for the moderating roles of the degree of gender inequality in the country of origin (Hypothesis 3) and the destination (Hypothesis 4), and their relative importance.

All the estimation results include Driscoll-Kraay standard errors, which are robust to heteroskedasticity, autocorrelation, and cross-sectional dependence in the residuals (Driscoll and Kraay, 1998). As highlighted by Hoechle (2007), Driscoll-Kraay standard errors are robust to very general forms of spatial and temporal dependence, which are likely to emerge in large-scale micro-econometric panel data sets like the one we use. In our case, there might be unobserved inter-sector and inter-province effects for the creation of new firms by

\footnotetext{
${ }^{8} \mathrm{~A}$ potential concern is that GEIs are at the NUTS-2 level (i.e. 20 Italian administrative regions). In Appendix B, we use a series of other proxies for the degree of gender inequality in the destination, at the more disaggregated NUTS-3 level (i.e. Italian provinces). They include proxies based on the presence of women in political and entrepreneurial activities and are constructed starting from either ISTAT data or the ASIA data set.

${ }^{9}$ The four categories are the following: (i) less gender-unequal countries of origin and less gender-unequal destinations; (ii) less gender-unequal countries of origin and more gender-unequal destinations; (iii) more gender-unequal countries of origin and less gender-unequal destinations; and (iv) more gender-unequal countries of origin and more gender-unequal destinations.
} 
immigrant entrepreneurs, which could result in cross-sectional dependence. Therefore, it is crucial for unbiased inference to use standard errors robust to such types of correlation in the error terms. Driscoll-Kraay standard errors are increasingly used in large micro-econometric panel data sets (e.g. Ammann et al., 2011; Bradley et al., 2019; Deutsch et al., 2010). ${ }^{10}$

Table 2 presents the results for the estimation of Equation (1). We estimate several specifications of Equation (1), which progressively add control variables. Starting from a basic regression that only controls for time effects (Specification 1), we add controls for industry, province, and country of origin fixed effects (Specification 2). Specifications 3, 4, and 5 progressively add controls for the interactions between time effects and industry (Specification 3), province (Specification 4), and country of origin (Specification 5) fixed effects. Specification 6 further controls for the (lagged) immigration rate by province and country of origin. Specification 7 also controls for the (lagged) stock of entrepreneurs by province and industry. Lastly, Specification 8 is a variant of Specification 7, in which we split the stock of such entrepreneurs between Italian and non-Italian entrepreneurs.

Our estimation results show a significant attractiveness effect, which is exceptionally stable to the introduction of the many controls described.

This result confirms our first hypothesis, that the higher the stock of immigrant entrepreneurs, the higher is the formation of new firms of same-nationality entrepreneurs in the same sector and province. Although it is based on a different empirical approach, this evidence is in line with the study by Tavassoli and Trippl (2019), who show for Sweden that an immigrant's decision to become an entrepreneur is positively affected by being located in a region with a large portion of 'same ethnics-same sector' immigrant entrepreneurs. Their estimates show that increasing the share of 'same ethnics-same sector' immigrant entrepreneurs from its sample minimum (0) to its theoretical maximum (100) is associated with an increase by 240 percentage points in the probability of an immigrant's decision to become an entrepreneur. We find that the attractiveness effect ranges from a maximum of 0.365 in Specification 1 to a minimum of 0.353 in Specification 2. These coefficients cannot be directly compared to those of Tavassoli and Trippl (2019) since they do not measure the individual probability of becoming an entrepreneur, but rather capture an aggregate effect. In particular, they show that, on average, roughly an additional $35 \%$ of new entrepreneurs from a given nationality decide to locate in a given province and sector due to the existing stock of firms of the same country of origin in the same sector and province. Put another way, $35 \%$ of new immigrant firms are explained by the existing stock of firms set up by

\footnotetext{
${ }^{10}$ We thank an anonymous referee for having raised this issue. Notably, the STATA programs used to obtain Driscoll-Kraay standard errors are 'reghdfe' and 'ivreghdfe', which have been recently developed by Sergio Correia.
} 
same-nationality immigrants, for each sector and province.

[Insert Table 2 around here]

The attractiveness or pulling effect can be interpreted by relying on the concepts of mixed embeddedness (Jones et al., 2014; Kloosterman, 2010; Kloosterman et al., 1998, 1999; Price and Chacko, 2009) and role models (Bosma et al., 2012; Chlosta et al., 2012). First, placing a new firm in the same sector and province where there are firms of co-nationals gives access to social networks, which provide capital, support, knowledge, and a supply or customer base. Therefore, it is easier to start a new firm by using the experience of the same co-nationals in the same sector of activity and province through a learning-by-support mechanism. Second, characteristics such as geographic location, sector, and nationality facilitate role identification of would-be entrepreneurs through a 'learning-by-example' mechanism (i.e. 'role model' effect), possibly leading to a geographical and sectoral clustering of co-national immigrant entrepreneurs.

As previously mentioned, we have used several tests to assess the robustness of our results. In particular, we have tested the use of alternative time lags in the regressors (i.e. one- and three-year lags), we have conducted instrumental variable estimation based on the shift-share instrument proposed in Card (2001), and explored the presence of interaction effects between the stock of entrepreneurs from a given country, in a given province and sector, and the presence in that province of same-nationality immigrants. The results for these robustness checks are presented and discussed in Appendix A. All these tests confirm a significant positive attractiveness effect, with a stable magnitude.

However, are these effects homogeneous by gender? We add the gender dimension to our reasoning to detect whether, and to what extent, women and men differ in the attractiveness effect. In Table 3, we first present the results for the estimations of Equations (2) and (3) (first panel of the table), from which we obtain gender differences in the attractiveness effect as the difference between $\beta_{m}$ (i.e. the attractiveness effect for males) and $\beta_{f}$ (i.e. the attractiveness effect of females). The second panel of Table 3 presents the estimation results of Equations (4) and (5), which distinguish between the effect stemming from same-gender and that stemming from other-gender entrepreneurs. Note that these and all the following estimations include the same set of controls as Specification 7 of Table 2, thereby accounting for a rich list of fixed effects, the immigration rate by province and nationality, and the stock of same-province and same-industry entrepreneurs.

Our results show that the relation between the stock of immigrant entrepreneurs and the formation of new firms of same-nationality entrepreneurs in the same sector and province is stronger for men than for women (Model 1, first panel of the table). While the elasticity is 
0.302 for men, it decreases to 0.169 for women. The difference between the two coefficients is sizeable (0.133) and highly significant, thereby pointing to a substantial gender gap in the attractiveness effect. The results also show that the gender of the entrepreneur shapes the attractiveness effect differently. Women are less active than men in following other samegender entrepreneurs of the same nationality, in the same province and sector $(21.1 \%$ for female entrepreneurs against $32.9 \%$ for male ones, Model 2, second panel of the table). It is also important to note that the other-gender attractiveness effect (i.e. how men respond to women and how women respond to men) is much smaller than the same-gender effect for both women and men. Finally, women are more attracted by men than men are by women $(5.8 \%$ versus $1.6 \%)$.

[Insert Table 3 around here]

Overall, these results confirm our second hypothesis and support the idea that men and women differ in the way they build, use, and leverage their networks. In particular, it appears that women are less effective than men in exploiting social networks to become entrepreneurs. This result is in line with the literature on networks suggesting that women entrepreneurs have fewer networks compared to their male counterparts (Aldrich, 1989; Cromie and Birley, 1992; Hanson and Blake, 2009; Munch et al., 1997). Finally, concerning the effect stemming from same-gender and other-gender entrepreneurs, the results of Model 2 show that 'learningby-example' mechanisms are in place, and that gender is a critical dimension of identification. In this respect, the smaller magnitude of the pulling effect for women might also reveal a paucity of role models in women's social networks.

Given the heterogeneous cultures of immigrant entrepreneurs, we explore whether gender differences in the pulling effect are affected by the degree of gender inequality in the country of origin of the immigrant entrepreneurs (Hypothesis 3). As discussed in Sections 3 and 4, we use GIIs and the percentages of women in parliament in the countries of origin to proxy for the levels of gender inequality in such countries. We first distinguish between nationalities with high (above the median) and low (below the median) GIIs and run the regressions models in Equations (2) and (3) separately for entrepreneurs originating from countries with low and high GIIs (i.e. these are regressions on split samples). The results presented in Table 4 (first panel) show that the gender differences in the relations between the stock of immigrant entrepreneurs and the formation of new firms by entrepreneurs of the same nationality in the same sector and province are more prominent for immigrants coming from more gender-unequal countries. The results show that women are less active than men in following other entrepreneurs of the same nationality, in the same province and sector, if the country of origin has high gender inequality (i.e. high GIIs). The attractiveness 
effect in such cases is $12.9 \%$ for female entrepreneurs and $36.8 \%$ for male entrepreneurs, with a strongly significant gender difference of as much as $23.9 \%$. On the contrary, males and females are equally responsive if their country of origin is more gender-equal (i.e. low GIIs). In this case, the estimated attractiveness effect is $21.2 \%$ for female entrepreneurs and $21.3 \%$ for male entrepreneurs, with no significant difference. Similar results are obtained when, instead of using GIIs, we proxy gender inequality in the countries of origin through the percentages of women in parliament (see the second panel of Table 4). As with the GIIs, we proceed by separately estimating Equations (2) and (3) for entrepreneurs originating from countries with high (above the median) and low (below the median) female representation in origin countries' parliaments. Much higher gender differences emerge for entrepreneurs from countries with low female representation in parliament compared to countries with high female percentages in parliament (23.1\% as opposed to $4.8 \%$ ).

[Insert Table 4 around here]

These results are in line with the literature on the socio-economic determinants of gender differences in entrepreneurship (Maniyalath and Narendran, 2016) and confirm our third hypothesis. In gender-unequal countries, where there are sharp differences between men and women in educational levels and labour market participation, women are characterized by a less intense and effective networking activity, which results in a lower pulling effect (Aldrich, 1989; Cromie and Birley, 1992; Hanson and Blake, 2009; Munch et al., 1997). Overall, we cannot conclude that strong ties are less effective for entrepreneurship than weak ties, but this seems to depend on socio-economic factors and possibly also on the type of entrepreneurial activity. At the same time, low levels of empowerment and economic status within less equal communities can signal the paucity of role models within the community. ${ }^{11}$

However, does gender inequality in the destination also matter? To test Hypothesis 4, we proxy the degree of gender inequality in the destination by using GEIs. As before, we split the sample between regions of destination with high (above the median) and low (below the median) levels of GEIs, and run separate estimations of Equations (2) and (3) for entrepreneurs located in these two categories of regions. Table 5 shows the results for this. From the table, it emerges that the pulling effect is higher for men than for women irrespective of the level of gender inequality in the destination. The gender difference in the attractiveness effect is $14.5 \%$ in destinations with high GEIs (i.e. high gender equality) and $12.2 \%$ in destinations with low GEIs (i.e. low gender equality).

\footnotetext{
${ }^{11}$ We also conducted robustness tests that consider only the top 75 th and the bottom 25 th percentiles in terms of GIIs, that is, entrepreneurs originating from countries with very high and very low levels of GIIs, respectively. The results, available upon request, are consistent with the findings of Table 4.
} 
[Insert Table 5 around here]

As highlighted before, GEIs are at the NUTS-2 level, which identifies the 20 Italian administrative regions. A potential concern is that this relatively more aggregate categorization could provide only little variation in the data, which could at least partly drive the observed result, that is, that the degree of gender inequality in the destination does not influence gender differences in the attractiveness effect. ${ }^{12}$

To address this issue, we have conducted a variety of robustness checks based on the use of three different proxies for the degree of gender inequality in the destination at the provincial level, which is more disaggregated (i.e. the NUTS-3 level). The results for these robustness tests are presented in Appendix B, in Tables B.1-B.4. The first two proxies relate to the participation of women in politics, which is a crucial aspect of female empowerment and a key indicator of gender inequality (UNDP, 2012). One proxy refers to the representation of females among city councilors in the province, whereas the other is based on the presence of women mayors in the province. These data are provided by the ISTAT at the municipal/annual level. We then aggregated such information at the provincial/annual level and matched it with the ASIA data used in this paper. The third proxy is constructed within the ASIA data set and refers, for each province and year, to the representation of females among native entrepreneurs. It provides a proxy for women's participation in entrepreneurial activities, which is also a crucial indicator of gender equality. We then proceeded as usual, and examined the gender differences separately for provinces with low and high gender inequality, as captured by each of the three proxies. As usual, high and low levels of the proxies are defined as those above and below their median values.

Table B.1 presents the results when we use the percentage of women city councilors in the province of destination as a proxy for gender inequality; Table B.2 refers to the proxy based on the presence of women mayors in the province of destination; lastly, Table B.3 presents the results when we consider the representation of females among native entrepreneurs in the province of destination. As a further robustness check, we have also considered the intersection of the three proxies to define provinces of destination characterized by low and high gender inequality and presented the results in Table B.4. What emerges from all these tests is that the degree of gender inequality in the province of destination is not important in explaining the gender differences in the attractiveness effect. The magnitude of the gender differences in provinces of destination with low and high gender inequality, as captured by the three distinct proxies and by their combination, is always very similar, thereby providing strong evidence that the degree of gender inequality in the destination does not play any

\footnotetext{
${ }^{12}$ We thank an anonymous referee for having raised this concern.
} 
significant role in driving gender differences in the pulling effect. Overall, the bulk of the evidence leads us to reject Hypothesis 4.

Lastly, we explicitly test the relative importance of the degree of gender inequality in the country of origin versus the destination. Table 6 presents the estimated gender differences in the attractiveness effect in the four possible configurations stemming from the interaction between the degree of gender inequality in the country of origin and region of destination (i.e. low/low, low/high, high/low, and high/high gender inequality in the country of origin and destination). Gender equality in the country of origin is proxied by the GIIs, whereas gender equality in the region of destination is proxied by the GEIs. The result that the degree of gender inequality in the country of origin is a crucial determinant of gender differences, whereas no important role is attributable to the degree of gender inequality in the destination, is confirmed. In particular, we observe that when immigrants come from countries with low levels of gender differences, the pulling effect is the same for men as for women (about $20 \%$ ), irrespective of the level of gender inequality in the region of destination. On the other hand, when immigrants come from gender-unequal countries, the pulling effect is much more prominent for men than for women, again, irrespective of the level of gender equality in the region of destination (the gender difference is $25.0 \%$ in regions of destination with high GEIs, and $22.8 \%$ in regions of destination with low GEIs). ${ }^{13}$

\section{[Insert Table 6 around here]}

These last results may be summarized by stating that the gender attitudes in the countries of origin fully determine the gender gap in the attractiveness effect: "no matter where you go, it matters where you come from.' This evidence indirectly supports theories of divergence suggesting that distinctive social values and norms are enduring and deep-rooted within each nation, shaped by collective histories, common languages, and religious traditions, so that immigrant populations are unlikely to abandon their cultural roots when they settle in another country (Norris and Inglehart, 2012).

\section{Conclusions}

Drawing on the concepts of mixed embeddedness and role models, we have examined whether the existing stock of immigrant firms induces more new firms of the same nationality in the same sector and province, while focussing on gender differences in this effect. In other

\footnotetext{
${ }^{13}$ Note that we have also estimated a version of Table 6 in which the degree of gender equality in the destination is based on the combination of the three provincial-level proxies described above. The results, presented in Table B.5 in Appendix B, are unchanged.
} 
words, we have added the dimension of gender to our reasoning so as to detect whether, and to what extent, the attractiveness effect differs between women and men. These are relevant issues since immigrant entrepreneurship is an important channel for fostering the entry of immigrants into the labour market, essential for promoting their integration and well-being. Focussing on the dynamics behind female immigrant entrepreneurship is crucial because entrepreneurship acts as a means of female empowerment. Female immigrants are typically among the weakest participants in the labour market, and, therefore, they can greatly benefit from undertaking an entrepreneurial activity.

The empirical analysis relies on administrative data about the population of individual firms observed over the period 2002-2013 in Italian NUTS-3 regions. Descriptive evidence shows that the proportion of immigrant entrepreneurs in the collection of all entrepreneurs in Italy has become significant, and that their weight has increased continually. A similar increasing trend is confirmed for female immigrant entrepreneurs, thereby suggesting the significance of the phenomenon under scrutiny in this paper.

Our econometric estimations provide strong and robust evidence that the existing stock of immigrant firms induces more new firms of the same nationality in the same sector and province. Similar results, although using a different method, were found in the case of Sweden by Tavassoli and Trippl (2019). The extension to the case of Italy suggests that also in this country, which is rather specific in the structure of its production - with a large share of small firms and relatively low levels of law enforcement - and which is facing sharp social tensions due to migration, immigrant entrepreneurship may contribute to the integration of immigrants into the labour market and may be favoured by the diffusion of institutional and industry-specific knowledge spillovers within the social networks of samenationality communities. Therefore, policy makers should acknowledge this critical channel for the creation of immigrant firms and try to stimulate it by taking steps to actively increase opportunities for knowledge spillovers among immigrants.

While the existence of a pulling effect of immigrant entrepreneurs has been documented in the literature, this is the first paper showing that this effect differs by gender. Women have a substantially lower pulling effect than men. In particular, we have shown that pulling effects are much weaker for women coming from gender-unequal countries. The paucity of role models and the less intense networking activity for women coming from countries with low levels of female labour market participation and education may explain this result. Furthermore, this effect holds irrespective of the level of gender inequality in the region of destination or the province of destination. This supports theories stating that cultural differences in ethnic communities persist - and, in some cases, are even enhanced - after migration. Although our results might reflect the selection of immigrants in terms of education and skills (i.e., 
countries characterized by high gender inequality are likely to differ in the distribution of human capital compared to more gender-equal countries), we believe they offer important hints in terms of policy implications.

From the policy standpoint, the expansion effect that a cluster of 'similar' immigrants can generate in terms of entrepreneurial activity is very relevant. Although it can be problematic to counteract these strong cultural effects, policy makers should be particularly alert to policies targeted to immigrants, particularly women. The relatively smaller network effect on women can produce more difficulties in finding possibilities for best practices exchange. Particularly in the case of women, and sometimes also for cultural reasons not only due to similarity, they might be more willing and at ease attending courses and events aimed at women only, and run in the mother tongue as well. Supporting the creation of more formal networks dedicated to women (especially those coming from more gender-unequal countries), whereby they can more easily get in touch with (possibly female) entrepreneurs, is also critical.

While we have explained gender differences in the pulling effect by referring to gender differences in social networks and to the concept of role models, future studies could better explore possible transmission channels at the theoretical level and provide further empirical evidence of their significance, also trying to disentangle the relative importance of alternative explanations. To what extent are personal attitudes, cultural factors, and socio-economic factors responsible for gender differences in the returns from social networks and in the importance of role models? Moreover, are there differences between different national groups? Furthermore, while we have explored the relative importance of gender inequality in the country of origin and in the region of destination of the immigrants in affecting gender differences in the pulling effect, it would be interesting to conceptually explore and empirically test whether the distance along some dimensions of gender gaps (cultural, socio-economic, etc.) between the country of origin and the destination, by affecting cultural assimilation, also contributes to explaining these differences.

In this paper, we have not distinguished between different generations of immigrants. Data providing such information would be extremely beneficial for testing whether assimilation increases and gender differences are reduced for second-generations of immigrants. Moreover, while attractiveness effects are a crucial channel for stimulating immigrant entrepreneurship, further work is needed to explore whether networks have an impact on firms' performance, including firms' growth and survival probability, and whether the impact varies by gender. Lastly, the roles of factors leading to sectoral diversification of immigrant entrepreneurship could also be explored, since diversification may help avoid some adverse outcomes of the pulling effect, such as lock-in and segregation. 


\section{References}

Acemoglu, D., Robinson, J. A., 2006. Economic Origins of Dictatorship and Democracy. Cambridge University Press, Cambridge, UK.

Acs, Z. J., Bardasi, E., Estrin, S., Svejnar, J., 2011. Introduction to Special Issue of Small Business Economics on Female Entrepreneurship in Developed and Developing Economies. Small Business Economics 37, 393-396.

Aldrich, H., 1989. Networking among Women Entrepreneurs. In: Hagan, O., Rivchun, C., Sexton, D. (Eds.), Women-Owned Businesses. Praeger Publishers, New York, NY, pp. $103-132$.

Amici, M., Stefani, M. L., 2013. A Gender Equality Index for the Italian Regions, Questioni di Economia e Finanza (Occasional papers) Banca d'Italia - Eurosistema, No. 190.

Ammann, M., Oesch, D., Schmid, M. M., 2011. Corporate Governance and Firm Value: International Evidence. Journal of Empirical Finance 18 (1), 36-55.

Anderson, B. R. O., 1983. Imagined Communities: Reflections on the Origin and Spread of Nationalism. Verso Books, London, UK.

Andersson, L., Hammarstedt, M., 2011. Transmission of Self-Employment across Immigrant Generations: The Importance of Ethnic Background and Gender. Review of Economics of the Household 9, 555-577.

Andersson, L., Hammarstedt, M., 2015. Ethnic Enclaves, Networks and Self-Employment among Middle Eastern Immigrants in Sweden. International Migration 53 (6), 27-40.

Andersson, M., Larsson, J. P., 2016. Local Entrepreneurship Clusters in Cities. Journal of Economic Geography 16 (1), 39-66.

Audretsch, D. B., Lehmann, E. E., 2005. Does the Knowledge Spillover Theory of Entrepreneurship Hold for Regions? Research Policy 34 (8), 1191-1202.

Basiglio, S., De Vincentiis, P., Isaia, E., Rossi, M., 2019. Credit Access and Approval, CERP Working Paper, No. 189/19.

Baumeister, R. F., Sommer, K. L., 1997. What Do Men Want? Gender Differences and Two Spheres of Belongingness: Comment on Cross and Madson. Psychological Bulletin 122 (1), $38-44$. 
Beaman, L., Keleher, N., Magruder, J., 2018. Do Job Networks Disadvantage Women? Evidence from a Recruitment Experiment in Malawi. Journal of Labor Economics 36 (1), $121-157$.

Benenson, J. F., 1993. Greater Preference among Females Than Males for Dyadic Interaction in Early Childhood. Child Development 64 (2), 544-555.

Bertrand, M., 2011. New Perspectives on Gender. In: Card, D., Ashenfelter, O. (Eds.), Handbook of Labor Economics. Vol. 4B. Elsevier, Amsterdam, The Netherlands, pp. 15431590.

Booth, A., 1972. Sex and Social Participation. American Sociological Review 37 (2), 183-193.

Bosma, N., Hessels, J., Schutjens, V., Van Praag, M., Verheul, I., 2012. Entrepreneurship and Role Models. Journal of Economic Psychology 3 (2), 410-424.

Bradley, C., Brennan, J., Wagner, B., 2019. Workplace Injury Rates and Firm-Level Turnover in Montana's Oil and Gas Industry. American Journal of Industrial Medicine 62 (6), 535541.

Brush, C. G., 1992. Research on Women Business Owners: Past Trends, a New Perspective and Future Directions. Entrepreneurship: Theory and Practice 16 (4), 5-30.

Card, D., 2001. Immigrant Inflows, Native Outflows, and the Local Market Impacts of Higher Immigration. Journal of Labor Economics 19 (1), 22-64.

Chlosta, S., Patzelt, H., Klein, S. B., Dormann, C., 2012. Parental Role Models and the Decision to Become Self-Employed: The Moderating Effect of Personality. Small Business Economics 38 (1), 121-138.

Cromie, S., Birley, S., 1992. Networking by Female Business Owners in Northern Ireland. Journal of Business Venturing 7 (3), 237-251.

Damm, A. P., 2009. Ethnic Enclaves and Immigrant Labor Market Outcomes: QuasiExperimental Evidence. Journal of Labor Economics 27 (2), 281-314.

Davidsson, P., Wiklund, J., 1997. Values, Beliefs and Regional Variations in New Firm Formation Rates. Journal of Economic Psychology 18 (2-3), 179-199.

Deutsch, Y., Keil, T., Laamanen, T., 2010. A Dual Agency View of Board Compensation: The Joint Effects of Outside Director and CEO Stock Options on Firm Risk. Strategic Management Journal 32 (2), 212-227. 
Driscoll, J. C., Kraay, A. C., 1998. Consistent Covariance Matrix Estimation with Spatially Dependent Panel Data. Review of Economics and Statistics 80 (4), 549-560.

Elam, A., Terjesen, S., 2010. Gendered Institutions and Cross-National Patterns of Business Creation for Men and Women. European Journal of Development Research 22 (3), 331348.

Elfring, T., Hulsink, W., 2003. Networks in Entrepreneurship: The Case of High-Technology Firms. Small Business Economics 21, 409-422.

Foged, M., Peri, G., 2016. Immigrants' Effect on Native Workers: New Analysis on Longitudinal Data. American Economic Journal: Applied Economics 8 (2), 1-34.

Fornahl, D., 2003. Entrepreneurial Activities in a Regional Context. In: Fornahl, D., Brenner, T. (Eds.), Cooperation, Networks, and Institutions in Regional Innovations Systems. Edward Elgar Publishing, Cheltenham, UK, pp. 38-57.

Friebel, G., Lalanne, M., Richter, B., Schwardmann, P., Seabright, P., 2017. Women Form Social Networks More Selectively and Less Opportunistically than Men, SAFE Working Paper, No. 168.

Fritsch, M., Wyrwich, M., 2014. The Long Persistence of Regional Levels of Entrepreneurship: Germany, 1925-2005. Regional Studies 48 (6), 955-973.

Fullin, G., Reyneri, E., 2010. Low Unemployment and Bad Jobs for New Immigrants in Italy. International Migration 49 (1), 118-147.

Gibson, D. E., 2004. Role Models in Career Development: New Directions for Theory and Research. Journal of Vocational Behavior 65 (1), 134-156.

Granovetter, M. S., 1973. The Strength of Weak Ties. American Journal of Sociology 78 (6), 1360-1380.

Granovetter, M. S., 1974. Getting a Job: A Study of Contacts and Careers. Harvard University Press, Cambridge, MA.

Guiso, L., Schivardi, F., 2011. What Determines Entrepreneurial Clusters? Journal of the European Economic Association 9 (1), 61-86.

Hanson, S., Blake, M., 2009. Gender and Entrepreneurial Networks. Regional Studies 43 (1), 135-149. 
Hernandez, A. E., 1995. Do Role Models Influence Self Efficacy and Aspirations in Mexican American at-Risk Females? Hispanic Journal of Behavioral Sciences 17 (2), 256-263.

Hoechle, D., 2007. Robust Standard Errors for Panel Regressions with Cross-Sectional Dependence. Stata Journal 7 (3), 281-312.

Ibarra, H., 1992. Homophily and Differential Returns: Sex Differences in Network Structure and Access in an Advertising Firm. Administrative Science Quarterly 37 (3), 422-447.

Jones, T., Ram, M., Edwards, P., Kiselinchev, A., Muchenje, L., 2014. Mixed Embeddedness and New Migrant Enterprise in the UK. Entrepreneurship \& Regional Development 26 (56), 500-520.

Kerr, W. R., Mandorff, M., 2016. Social Networks, Ethnicity, and Entrepreneurship, CESifo Working Paper, No. 6211.

Kloosterman, R. C., 2010. Matching Opportunities with Resources: A Framework for Analysing (Migrant) Entrepreneurship from a Mixed Embeddedness Perspective. Entrepreneurship and Regional Development 22 (1), 25-45.

Kloosterman, R. C., van der Leun, J., Rath, J., 1998. Across the Border: Immigrants' Economic Opportunities, Social Capital and Informal Business Activities. Journal of Ethnic and Migration Studies 24 (2), 249-268.

Kloosterman, R. C., Van Der Leun, J., Rath, J., 1999. Mixed Embeddedness: (In)formal Economic Activities and Immigrant Businesses in the Netherlands. International Journal of Urban and Regional Research 23 (2), 252-266.

Klyver, K., Grant, S., 2010. Gender Differences in Entrepreneurial Networking and Participation. International Journal of Gender and Entrepreneurship 2 (3), 213-227.

Krueger JR, N. F., Reilly, M. D., Carsrud, A. L., 2000. Competing Models of Entrepreneurial Intentions. Journal of Business Venturing 15 (5-6), 411-432.

Krumboltz, J. D., Mitchell, A. M., Jones, G. B., 1976. A Social Learning Theory of Career Selection. The Counseling Psychologist 6 (1), 71-81.

Lafuente, E., Vaillant, Y., Rialp, J., 2007. Regional Differences in the Influence of Role Models: Comparing the Entrepreneurial Process of Rural Catalonia. Regional Studies 41 (6), 779-796. 
Lalanne, M., Seabright, P., 2011. The Old Boy Network: Gender Differences in the Impact of Social Networks on Remuneration in Top Executive Jobs, CEPR Discussion Papers, No. 8623.

Light, I. H., Bhachu, P., Karageorgis, S., 1993. Migration Networks and Immigrant Entrepreneurship. In: Light, I. H., Bhachu, P. (Eds.), Immigration and Entrepreneurship. Culture, Capital, and Ethnic Networks. Transactions Publishers, Piscataway, NJ, pp. 2550 .

Lindenlaub, I., Prummer, A., 2014. Gender, Social Networks and Performance, Cambridge Working Paper in Economics, No. 1461.

Maccoby, E. E., Jacklin, C. N., 1974. The Psychology of Sex Differences. Stanford University Press, Stanford, CA.

Maniyalath, N., Narendran, R., 2016. The Human Development Index Predicts Female Entrepreneurship Rates. International Journal of Entrepreneurial Behavior \& Research 22 (5), $745-766$.

Mengel, F., 2020. Gender Differences in Networking. The Economic Journal, online first.

Minniti, M., 2005. Entrepreneurship and Network Externalities. Journal of Economic Behavior \& Organization 57 (1), 1-27.

Moore, G., 1990. Structural Determinants of Men's and Women's Personal Networks. American Sociological Review 55 (5), 726-735.

Mueller, P., 2006. Entrepreneurship in the Region: Breeding Ground for Nascent Entrepreneurs? Small Business Economics 27 (1), 41-58.

Munch, A., McPherson, J. M., Smith-Lovin, L., 1997. Gender, Children, and Social Contact: The Effects of Childrearing for Men and Women. American Sociological Review 62 (4), $509-520$.

Nathan, M., 2014. The Wider Economic Impacts of High-Skilled Migrants: A Survey of the Literature for Receiving Countries. IZA Journal of Migration 3 (4).

Nathan, M., 2015. After Florida: Towards an Economics of Diversity. European Urban and Regional Studies 22 (1), 3-19.

Ndofor, H. A., Priem, R. L., 2011. Immigrant Entrepreneurs, the Ethnic Enclave Strategy, and Venture Performance. Journal of Management 37 (3), 790-818. 
Norris, P., Inglehart, R. F., 2012. Muslim Integration into Western Cultures: Between Origins and Destinations. Political Studies 60 (2), 228-251.

OECD, 2010a. Entrepreneurship and Migrants. Tech. rep., OECD, Paris, France.

OECD, 2010b. Migrant Entrepreneurship in OECD Countries. Tech. rep., OECD, Paris, France.

OECD, 2014. Enhancing Women's Economic Empowerment through Entrepreneurship and Business Leadership in OECD Countries. Tech. rep., OECD, Paris, France.

OECD, 2017. Policy Brief on Women's Entrepreneurship. Tech. rep., OECD, Paris, France.

Oggero, N., Rossi, M., Ughetto, E., 2019. Entrepreneurial Spirits in Women and Men. The Role of Financial Literacy and Digital Skills, CERP Working Paper, No. 187/19.

Ottaviano, G. I. P., Peri, G., 2006. The Economic Value of Cultural Diversity: Evidence from US Cities. Journal of Economic Geography 6 (1), 9-44.

Pathak, S., Goltz, S., Buche, M. W., 2013. Influences of Gendered Institutions on Women's Entry into Entrepreneurship. International Journal of Entrepreneurial Behaviour \& Research 19 (5), 478-502.

Peri, G., Romiti, A., Rossi, M., 2015. Immigrants, Domestic Labor and Women's Retirement Decisions. Labour Economics 36, 18-34.

Price, M., Chacko, E., 2009. The Mixed Embeddedness of Ethnic Entrepreneurs in a New Immigrant Gateway. Journal of Immigrant \& Refugee Studies 7 (3), 328-346.

Raijman, R., Tienda, M., 2000. Immigrants' Pathways to Business Ownership: A Comparative Ethnic Perspective. The International Migration Review 34 (3), 682-706.

Rodríguez-Pose, A., von Berlepsch, V., 2014. When Migrants Rule: The Legacy of Mass Migration on Economic Development in the United States. Annals of the Association of American Geographers 104 (3), 628-651.

Ruef, M., Aldrich, H. E., Carter, N. M., 2003. The Structure of Founding Teams: Homophily, Strong Ties, and Isolation among U.S. Entrepreneurs. American Sociological Review 68 (2), 195-222.

Sahin, M., Nijkamp, P., Baycan, T., 2007. Migrant Entrepreneurship from the Perspective of Cultural Diversity. In: Dana, L. P. (Ed.), Handbook of Research on Ethnic Minority Entrepreneurship. Edward Elgar Publishing, Cheltenham, UK, pp. 99-113. 
Slack, J., 2005. The New Entrepreneur Scholarships: Self-Employment as a Means to Tackle Social Deprivation. Education \& Training 47 (6), 447-455.

Sternberg, R., 2009. Regional Dimensions of Entrepreneurship. Foundations and Trends ${ }^{\circledR}$ in Entrepreneurship 5 (4), 211-340.

Sullivan, D. M., Meek, W. R., 2012. Gender and Entrepreneurship: A Review and Process Model. Journal of Managerial Psychology 27 (5), 428-458.

Tavassoli, S., Trippl, M., 2019. The Impact of Ethnic Communities on Immigrant Entrepreneurship: Evidence from Sweden. Regional Studies 53 (1), 67-79.

UNDP, 2012. Empowering Women for Stronger Political Parties, A Guidebook to Promote Women's Political Participation. Tech. rep., United Nations Development Programme (UNDP), New York, NY.

Urbano, D., Alvarez, C., 2014. Institutional Dimensions and Entrepreneurial Activity: an International Study. Small Business Economics 42 (4), 703-716.

Van Auken, H., Fry, F. L., Stephens, P., 2006a. The Influence of Role Models on Entrepreneurial Intentions. Journal of Developmental Entrepreneurship 11 (2), 157-167.

Van Auken, H., Stephens, P., Fry, F. L., Silva, J., 2006b. Role Model Influences on Entrepreneurial Intentions: A Comparison between USA and Mexico. The International Entrepreneurship and Management Journal 2 (3), 325-336.

Verheul, I., Risseeuw, P., Bartelse, G., 2002. Gender Differences in Strategy and Human Resource Management: The Case of Dutch Real Estate Brokerage. International Small Business Journal 20 (4), 443-476.

Wyrwich, M., Sternberg, R., Stuetzer, M., 2019. Failing Role Models and the Formation of Fear of Entrepreneurial Failure: A Study of Regional Peer Effects in German Regions. Journal of Economic Geography 19 (3), 567-588. 
Figure 1: Total number of entrepreneurs by year

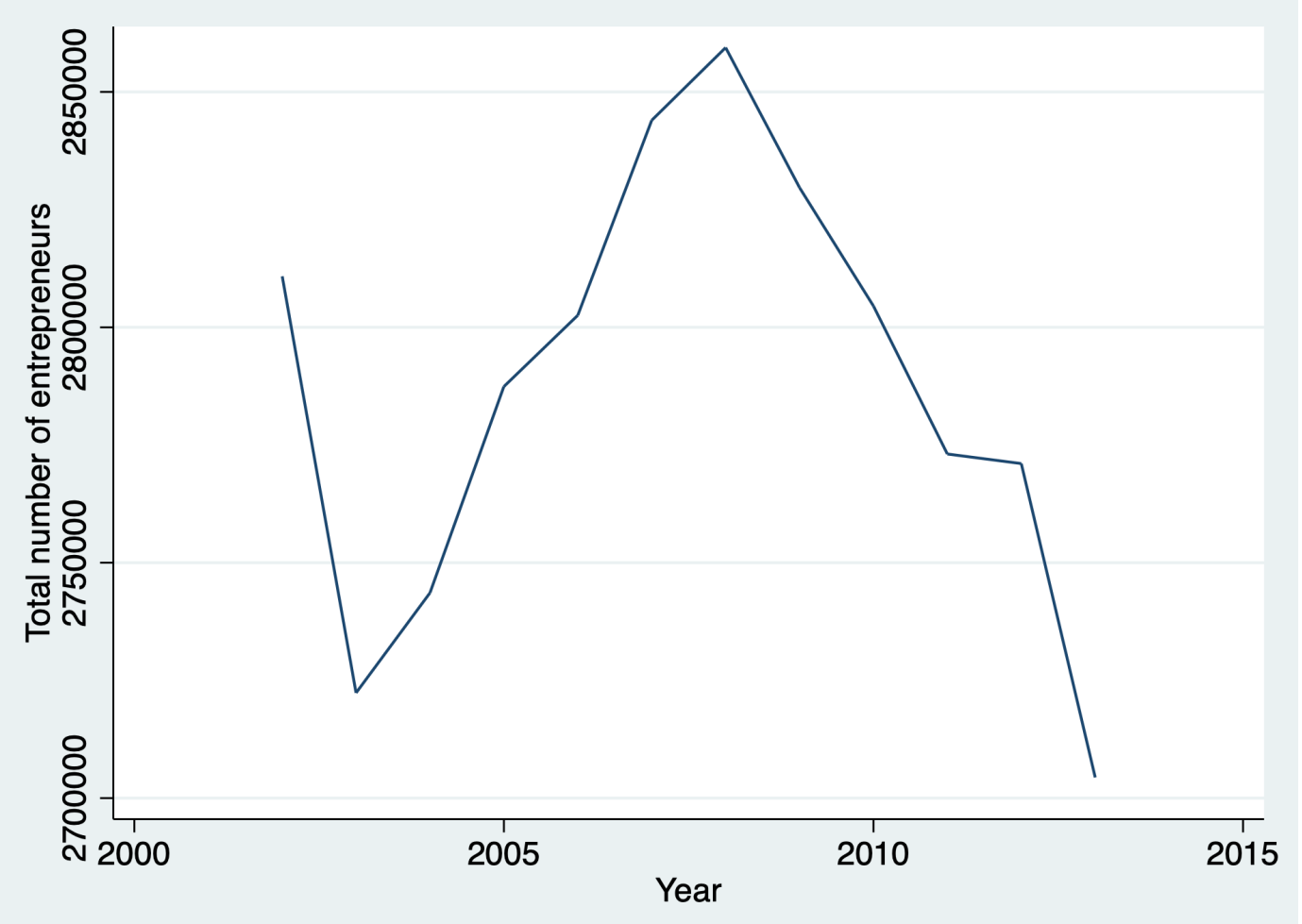

Source: ASIA data set (2002-2013) 
Figure 2: Ratio of female entrepreneurs to all entrepreneurs and ratio of immigrant entrepreneurs to all entrepreneurs by year

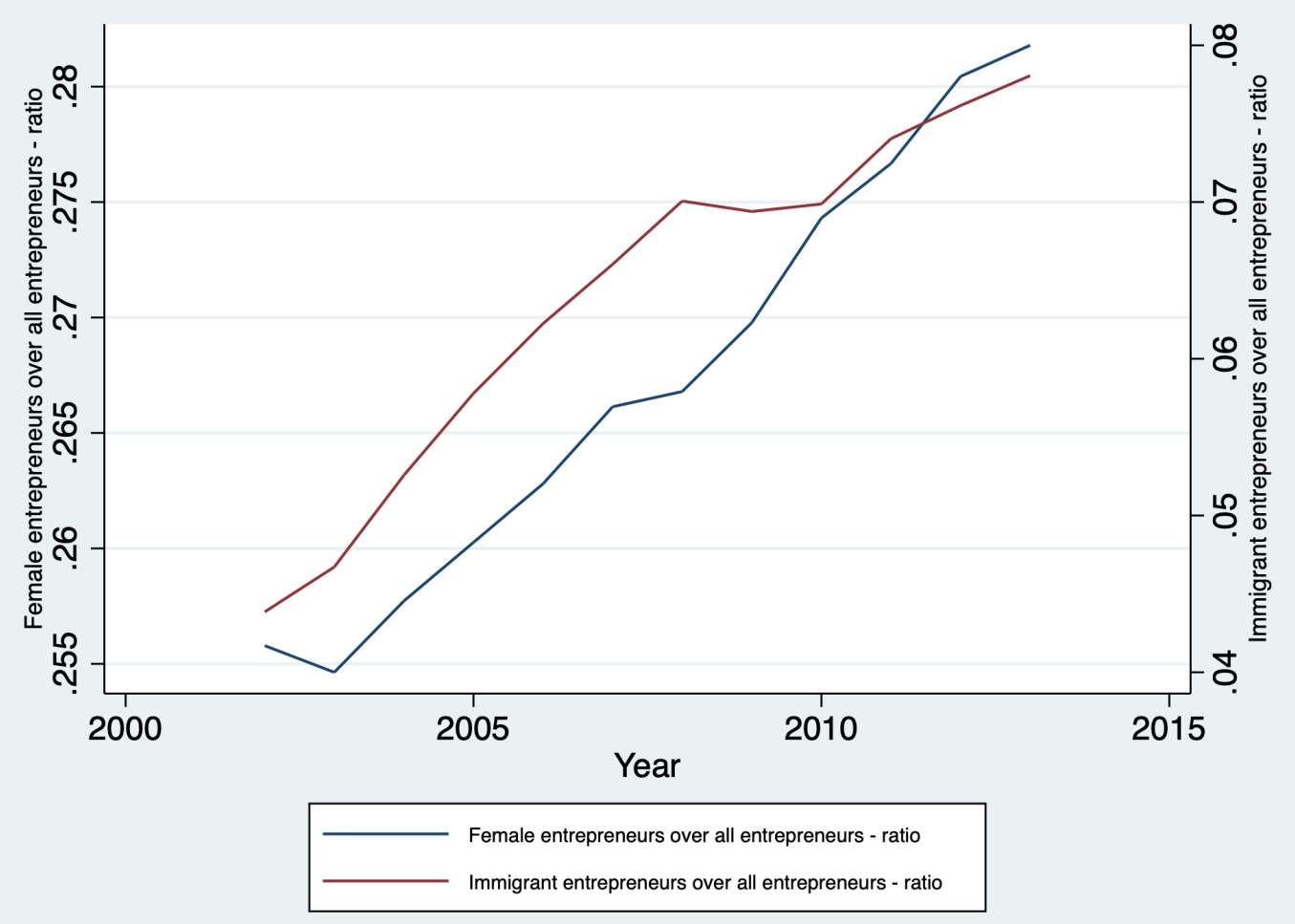

Source: ASIA data set (2002-2013) 
Figure 3: Ratio of female immigrant entrepreneurs to immigrant entrepreneurs and ratio of female immigrant entrepreneurs to female entrepreneurs by year

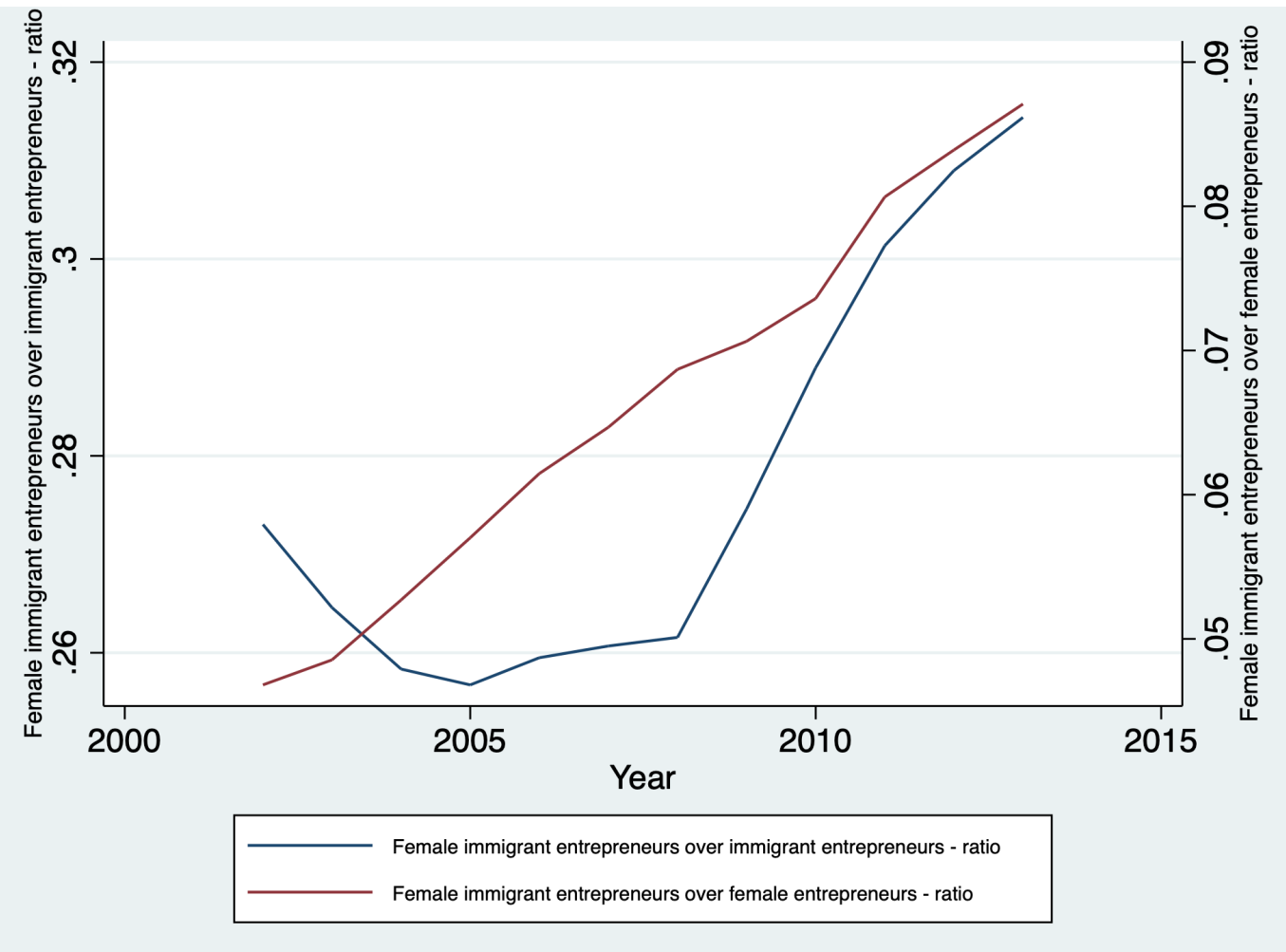

Source: ASIA data set (2002-2013) 
Figure 4: Total number of entrepreneurs by province (2013)

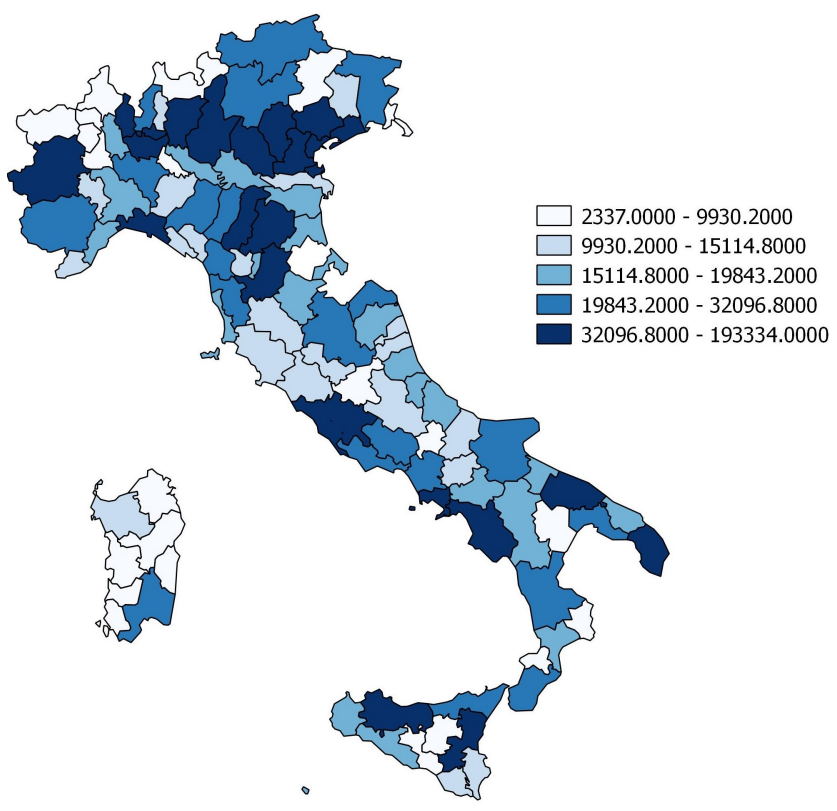

Source: ASIA data set (2002-2013)

Figure 5: Ratio of female entrepreneurs to all entrepreneurs by province (2013)

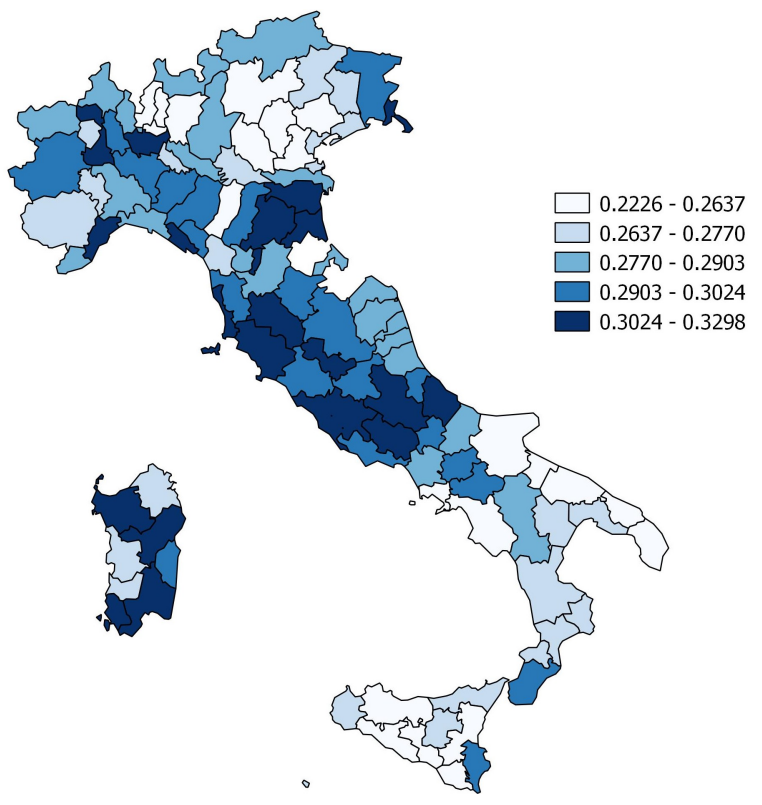

Source: ASIA data set (2002-2013) 
Figure 6: Ratio of immigrant entrepreneurs to all entrepreneurs by province (2013)

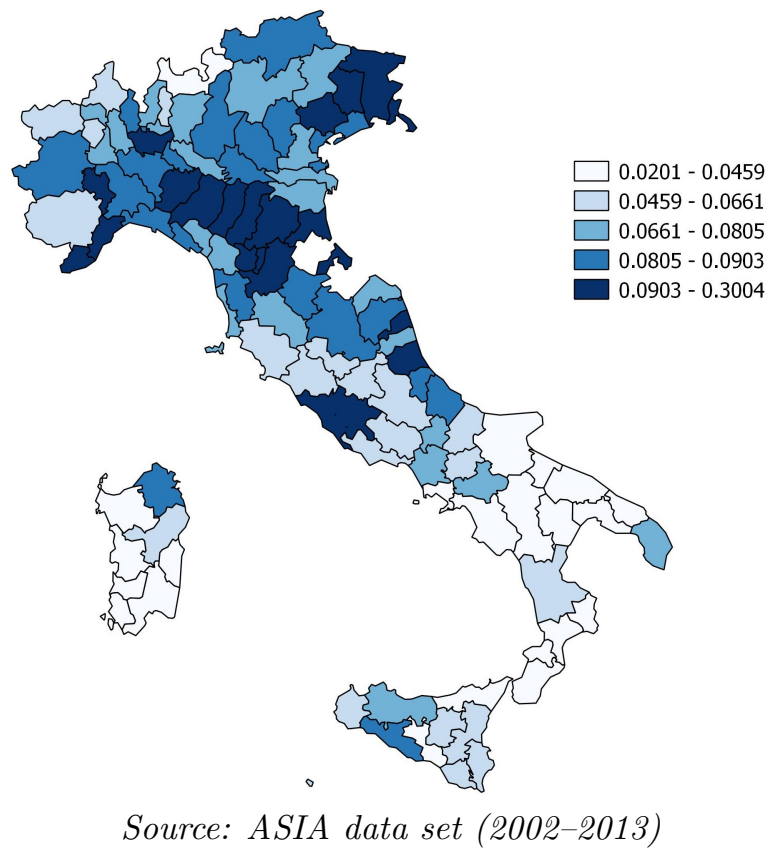

Figure 7: Ratio of female immigrant entrepreneurs to female entrepreneurs by province (2013)

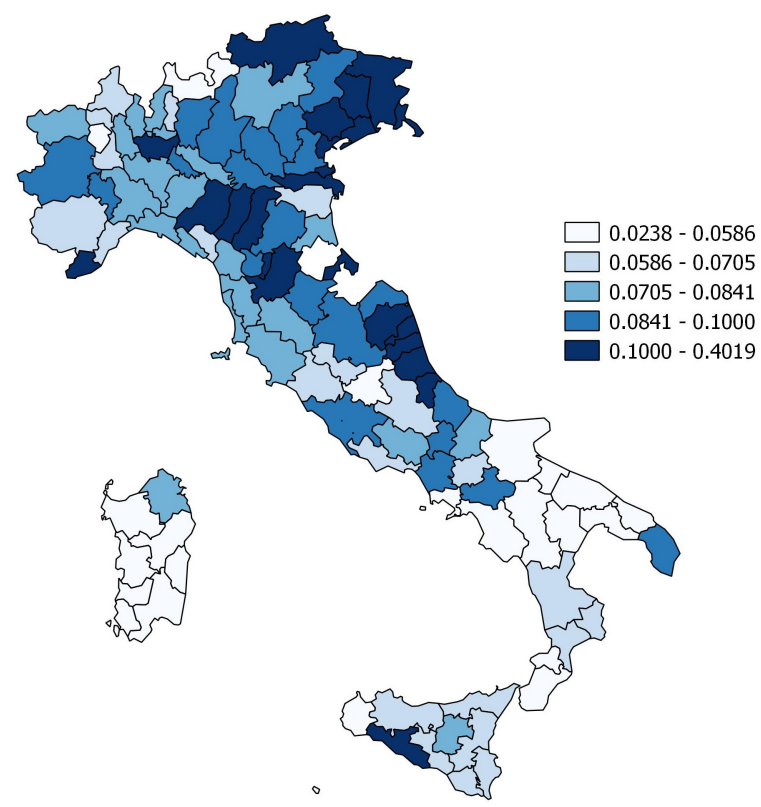

Source: ASIA data set (2002-2013) 


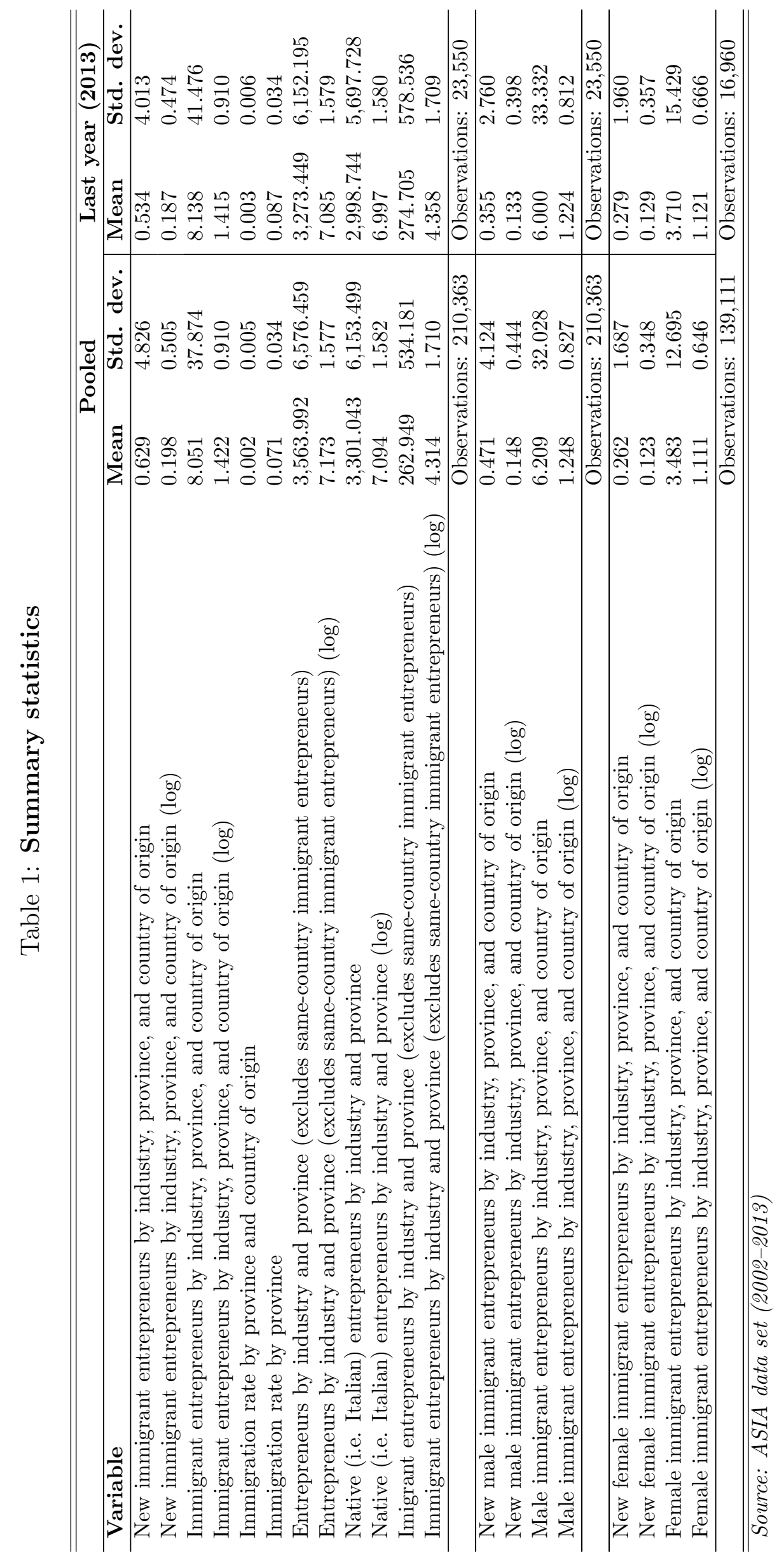







Table 3: Effect for males and females separately

\begin{tabular}{|c|c|c|c|}
\hline & Males & Females & $\begin{array}{l}\text { Gender dif- } \\
\text { ference }\end{array}$ \\
\hline & $\begin{array}{l}\text { Dep. var.: Number of } \\
\text { new male immigrant en- } \\
\text { trepreneurs by industry, } \\
\text { province, and country of } \\
\text { origin at t (log) }\end{array}$ & $\begin{array}{l}\text { Dep. var.: Number of } \\
\text { new female immigrant en- } \\
\text { trepreneurs by industry, } \\
\text { province, and country of } \\
\text { origin at }(\mathrm{log})\end{array}$ & \\
\hline \multicolumn{4}{|c|}{$\begin{array}{l}\text { Model 1: Effect stemming from all entrepreneurs } \\
\end{array}$} \\
\hline $\begin{array}{l}\text { Number of immigrant en- } \\
\text { trepreneurs by industry, } \\
\text { province, and country of } \\
\text { origin at } t-2(\log )\end{array}$ & $0.302^{* * *} \quad(0.014)$ & $0.169^{* * *} \quad(0.006)$ & $-0.133^{* * *}$ \\
\hline \multicolumn{4}{|c|}{ Model 2: Effect stemming from same-gender and other-gender entrepreneurs } \\
\hline $\begin{array}{l}\text { Number of same-gender } \\
\text { immigrant entrepreneurs } \\
\text { by industry, province, and } \\
\text { country of origin at } t-2 \\
(\log )\end{array}$ & $0.329^{* * *} \quad(0.018)$ & $0.211^{* * *} \quad(0.008)$ & $-0.118^{* * *}$ \\
\hline $\begin{array}{l}\text { Number of other-gender } \\
\text { immigrant entrepreneurs } \\
\text { by industry, province, and } \\
\text { country of origin at } t-2 \\
(\log )\end{array}$ & $0.016^{*} \quad(0.008)$ & $0.058^{* * *}$ & $+0.042^{* * *}$ \\
\hline $\begin{array}{l}\text { Same-gender effect rela- } \\
\text { tive to other-gender effect }\end{array}$ & 20.563 & 3.638 & \\
\hline Number of observations & 210,363 & 139,111 & \\
\hline
\end{tabular}

Source: ASIA data set (2002-2013)

Estimation method: OLS. Driscoll-Kraay standard errors, robust to autocorrelation, heteroscedasticity, and cross-sectional dependence, in parentheses. ${ }^{* *},{ }^{* *}$, and $*$ denote, respectively, the $1 \%, 5 \%$, and $10 \%$ significance levels. All regressions include the same set of controls as Specification 7 of Table 2. 


\section{Table 4: Gender differences by degree of gender inequality in the country of origin}

\begin{tabular}{|c|c|c|c|}
\hline & Males & Females & $\begin{array}{l}\text { Gender dif- } \\
\text { ference }\end{array}$ \\
\hline & $\begin{array}{l}\text { Dep. var.: Number of } \\
\text { new male immigrant en- } \\
\text { trepreneurs by industry, } \\
\text { province, and country of } \\
\text { origin at } t \text { (log) }\end{array}$ & $\begin{array}{l}\text { Dep. var.: Number of } \\
\text { new female immigrant en- } \\
\text { trepreneurs by industry, } \\
\text { province, and country of } \\
\text { origin at } t \text { (log) }\end{array}$ & \\
\hline \multicolumn{4}{|c|}{ Gender differences by Gender Inequality Indexes (GIIs) in the country of origin } \\
\hline \multicolumn{4}{|c|}{ Countries of origin with low GIIs (i.e. low gender inequality) } \\
\hline $\begin{array}{l}\text { Number of immigrant en- } \\
\text { trepreneurs by industry, } \\
\text { province, and country of } \\
\text { origin at } t-2(\log )\end{array}$ & $0.213^{* * *} \quad(0.010)$ & $0.212^{* * *} \quad(0.007)$ & -0.001 \\
\hline Number of observations & 92,921 & 70,903 & \\
\hline \multicolumn{4}{|c|}{ Countries of origin with high GIIs (i.e. high gender inequality) } \\
\hline $\begin{array}{l}\text { Number of immigrant en- } \\
\text { trepreneurs by industry, } \\
\text { province, and country of } \\
\text { origin at } t-2(\log )\end{array}$ & $0.368^{* * *} \quad(0.016)$ & $0.129^{* * *} \quad(0.006)$ & $-0.239 * * *$ \\
\hline Number of observations & 99,160 & 58,398 & \\
\hline
\end{tabular}

Gender differences by percentages of women in parliament in the country of origin Countries of origin with high percentage of women in parliament

\begin{tabular}{l|l|l|l|l}
\hline $\begin{array}{l}\text { Number of immigrant en- } \\
\text { trepreneurs by industry, } \\
\text { province, and country of } \\
\text { origin at } t-2(\log )\end{array}$ & & $0.197^{* * *} \quad(0.007)$ & $-0.048^{* * *}$ \\
\hline Number of observations & 119,836 & 76,892 & \\
\hline \multicolumn{4}{c}{ Countries of origin with low percentage of women in parliament } & $-0.231^{* * *}$ \\
\hline $\begin{array}{l}\text { Number of immigrant en- } \\
\text { trepreneurs by industry, } \\
\text { province, and country of } \\
\text { origin at } t-2 \text { (log) }\end{array}$ & & $0.367^{* * *}(0.018)$ & & \\
\hline Number of observations & 89,884 & 61,951 & \\
\hline \hline
\end{tabular}

Source: ASIA data set (2002-2013)

Estimation method: OLS. Driscoll-Kraay standard errors, robust to autocorrelation, heteroscedasticity, and cross-sectional dependence, in parentheses. ${ }^{* * *},{ }^{* *}$, and ${ }^{*}$ denote, respectively, the $1 \%, 5 \%$, and $10 \%$ significance levels. All regressions include the same set of controls as Specification 7 of Table 2. GIIs are provided by UNDP in 2010 and refer to 2008. We use this version of GII, and not the most recent, as 2008 lies exactly half-way in our panel, which spans from 2002 to 2013. Unfortunately, GIIs for 2008 have not been reported for some (small) countries, which entails a loss of around $8 \%$ of the observations. Countries of origin with low (high) GIIs are defined as those below (above) the median. As with the GIIs, the percentages of women in parliament refer to 2008. For a few (small) countries, the 2008 percentage of women in parliament has not been reported, which entails a loss of around $0.3 \%$ of the observations. Countries of origin with low (high) percentage of women in parliament are defined as those below (above) the median. 


\section{Table 5: Gender differences by degree of gender inequality in the region of destination}

\begin{tabular}{|c|c|c|c|}
\hline & Males & Females & $\begin{array}{l}\text { Gender dif- } \\
\text { ference }\end{array}$ \\
\hline & $\begin{array}{l}\text { Dep. var.: Number of } \\
\text { new male immigrant en- } \\
\text { trepreneurs by industry, } \\
\text { province, and country of } \\
\text { origin at } t \text { (log) }\end{array}$ & $\begin{array}{l}\text { Dep. var.: Number of } \\
\text { new female immigrant en- } \\
\text { trepreneurs by industry, } \\
\text { province, and country of } \\
\text { origin at } t \text { (log) }\end{array}$ & \\
\hline \multicolumn{4}{|c|}{ Gender differences by Gender Equality Indexes (GEIs) in the region of destination } \\
\hline \multicolumn{4}{|c|}{ Regions of destination with high GEIs (i.e. low gender inequality) } \\
\hline $\begin{array}{l}\text { Number of immigrant en- } \\
\text { trepreneurs by industry, } \\
\text { province, and country of } \\
\text { origin at } t-2(\log )\end{array}$ & $0.313^{* * *} \quad(0.015)$ & $0.168^{* * *} \quad(0.007)$ & $-0.145^{* * *}$ \\
\hline Number of observations & 109,700 & 74,444 & \\
\hline \multicolumn{4}{|c|}{ Regions of destination with low GEIs (i.e. high gender inequality) } \\
\hline $\begin{array}{l}\text { Number of immigrant en- } \\
\text { trepreneurs by industry, } \\
\text { province, and country of } \\
\text { origin at } t-2(\log )\end{array}$ & $0.295^{* * *} \quad(0.013)$ & $0.173^{* * *} \quad(0.006)$ & $-0.122^{* * *}$ \\
\hline Number of observations & 100,663 & 64,667 & \\
\hline
\end{tabular}

Source: ASIA data set (2002-2013)

Estimation method: OLS. Driscoll-Kraay standard errors, robust to autocorrelation, heteroscedasticity, and cross-sectional dependence, in parentheses. ${ }^{* *}, * *$, and $*$ denote, respectively, the $1 \%, 5 \%$, and $10 \%$ significance levels. All regressions include the same set of controls as Specification 7 of Table 2 . GEIs are provided by Amici and Stefani (2013) and refer to 2010. Such indexes are only available for 2010 and are constructed based on the methodology behind GIIs of the UNDP. Regions of destination with low (high) GEIs are defined as those below (above) the median. 
Table 6: Gender differences by degree of gender inequality in the country of origin and degree of gender inequality in the region of destination

\begin{tabular}{|c|c|c|c|}
\hline & Males & Females & $\begin{array}{l}\text { Gender dif- } \\
\text { ference }\end{array}$ \\
\hline & $\begin{array}{l}\text { Dep. var.: Number of } \\
\text { new male immigrant en- } \\
\text { trepreneurs by industry, } \\
\text { province, and country of } \\
\text { origin at } t(\mathrm{log})\end{array}$ & $\begin{array}{l}\text { Dep. var.: Number of } \\
\text { new female immigrant en- } \\
\text { trepreneurs by industry, } \\
\text { province, and country of } \\
\text { origin at } t \text { (log) }\end{array}$ & \\
\hline \multicolumn{4}{|c|}{ Gender differences by GIIs in the country of origin and GEIs in the region of destination } \\
\hline \multicolumn{4}{|c|}{$\begin{array}{l}\text { Countries of origin with low GIIs (i.e. low gender inequality) } \\
\text { and regions of destination with high GEIs (i.e. low gender inequality) }\end{array}$} \\
\hline $\begin{array}{l}\text { Number of immigrant en- } \\
\text { trepreneurs by industry, } \\
\text { province, and country of } \\
\text { origin at } t-2(\log )\end{array}$ & $0.209^{* * *} \quad(0.010)$ & $0.216^{* * *} \quad(0.009)$ & +0.007 \\
\hline Number of observations & 44,987 & 36,213 & \\
\hline \multicolumn{4}{|c|}{$\begin{array}{l}\text { Countries of origin with low GIIs (i.e. low gender inequality) } \\
\text { and regions of destination with low GEIs (i.e. high gender inequality) }\end{array}$} \\
\hline $\begin{array}{l}\text { Number of immigrant en- } \\
\text { trepreneurs by industry, } \\
\text { province, and country of } \\
\text { origin at } t-2(\log )\end{array}$ & $0.217^{* * *} \quad(0.009)$ & $0.209^{* * *} \quad(0.006)$ & -0.008 \\
\hline Number of observations & 47,934 & 34,690 & \\
\hline \multicolumn{4}{|c|}{$\begin{array}{l}\text { Countries of origin with high GIIs (i.e. high gender inequality) } \\
\text { and regions of destination with high GEIs (i.e. low gender inequality) }\end{array}$} \\
\hline $\begin{array}{l}\text { Number of immigrant en- } \\
\text { trepreneurs by industry, } \\
\text { province, and country of } \\
\text { origin at } t-2(\log )\end{array}$ & $0.375^{* * *} \quad(0.018)$ & $0.125^{* * *} \quad(0.006)$ & $-0.250^{* * *}$ \\
\hline Number of observations & 54,161 & 32,419 & \\
\hline \multicolumn{4}{|c|}{$\begin{array}{l}\text { Countries of origin with high GIIs (i.e. high gender inequality) } \\
\text { and regions of destination with low GEIs (i.e. high gender inequality) }\end{array}$} \\
\hline $\begin{array}{l}\text { Number of immigrant en- } \\
\text { trepreneurs by industry, } \\
\text { province, and country of } \\
\text { origin at } t-2(\log )\end{array}$ & $0.362^{* * *} \quad(0.016)$ & $0.134^{* * *} \quad(0.007)$ & $-0.228^{* * *}$ \\
\hline Number of observations & 44,999 & 25,979 & \\
\hline
\end{tabular}

Source: ASIA data set (2002-2013)

Estimation method: OLS. Driscoll-Kraay standard errors, robust to autocorrelation, heteroscedasticity, and cross-sectional dependence, in parentheses. ***, **, and * denote, respectively, the $1 \%, 5 \%$, and $10 \%$ significance levels. All regressions include the same set of controls as Specification 7 of Table 2. Countries of origin and regions of destination with low and high GIIs and GEIs, respectively, are defined as in Tables 4 and 5. As noted in Table 4, unfortunately, GIIs for 2008 have not been reported for some (small) countries, which entails a loss of around $8 \%$ of the observations. 


\section{Appendices}

\section{A. Robustness I: Endogeneity and interaction effects}

In this appendix, we present several estimations aimed at testing the robustness of our results to endogeneity issues and interaction effects. The results for these tests are presented in Table A.1.

Models 1 and 2 of Table A.1 report the estimation of the coefficient of interest in the reference specification, which includes the same set of controls as in Specification 7 of Table 2 , but with regressors lagged by one period (i.e. at $t-1$ for Model 1 ) or three periods (i.e. at $t-3$ for Model 2). The estimated attractiveness effect in both cases is strongly significant, positive, and with magnitude virtually unchanged compared to when we use two-year lags (0.360 in the case of one-year lags, 0.345 in the case of three-year lags, whereas it is 0.356 in our reference estimation using two-year lags). Notably, we have conducted the full set estimations in Table 2 and experimented with several other results in Tables 3-6 with such different lag structures, and observed no changes in the results.

Model 3 instead presents the results from the instrumental variable estimation of Equation (1). Despite the use of lagged regressors and the inclusion of a wide array of fixed effects, endogeneity problems could still emerge. We have, therefore, resorted to an external instrument for our regressor of interest based upon the shift-share instrument in Card (2001), which has been used in many subsequent studies on migration issues (e.g. Foged and Peri, 2016; Ottaviano and Peri, 2006; Peri et al., 2015). The basic idea behind this instrument is to exploit the spatial variation in immigrant inflows for identification. To address the potential endogeneity of the choices of location of new immigrants (i.e. new immigrant entrepreneurs in our case), it combines immigration rates at an aggregate level (referred to as the 'aggregate shift component') with the lagged patterns of settlement of immigrants (referred to as the 'local shares component').

In practice, we rely on the geographic distribution of immigrants from each country of origin across the Italian provinces in 2002 (i.e. local shares component). We then consider the total country-specific stock of immigrants in Italy from 2007 to 2011 (i.e. aggregate shift component), which corresponds to at least 5 years after the initial geographic distribution of immigrants, and we finally distribute it according to the 2002 provincial shares for each country of origin. The instrument for our regressor of interest, Firms $s_{t-2, j, n}$, is the resulting imputed immigrant share, which varies at the provincial/annual level. It is denoted by $f_{t-2, p}$, and computed as follows.

$$
f_{t-2, p}=\frac{\sum_{c}\left(\frac{I_{2002, c, p}}{I_{2002, c}}\right) I_{t-2, c}}{p o p_{t-2, p}}
$$


with $t-2$ ranging from 2007 to 2011 . The term $\frac{I_{2002, c, p}}{I_{2002, c}}$ denotes the number of immigrants born in country $c$ and residing in province $p$ in 2002 relative to total immigrants from country $c$ residing in Italy in the same year. This fraction represents the local shares component, measured at $t^{0}$ (i.e. 2002). $I_{t-2, c}$ is the total number of immigrants from country $c$ present in Italy in $t-2$. This variable represents the aggregate shift component of the instrument. Lastly, $\operatorname{pop}_{t-2, p}$ is the total resident population of province $p$ at $t-2$. All these values are retrieved from ISTAT data. ${ }^{\text {A.1 }}$

The results for this IV estimation are presented in Model 3 of Table A.1. The estimated attractiveness effect is strongly significant, positive, and equal to 0.324 , thus very similar compared to the standard OLS estimations. ${ }^{\text {A.2 }}$

Finally, Model 4 of Table A.1 presents the results when we allow for the interaction between our regressor of interest and the immigration rate by province and country of origin. A positive and significant attractiveness effect, with a magnitude similar to the basic estimate ( 0.290 versus 0.356$)$, is detected irrespective of the presence of same-nationality immigrants in the province. However, a positive and significant interaction term emerges. A higher presence of immigrants from a given country in the province is, therefore, found to significantly potentiate the attractiveness effect, thereby suggesting that the size of the co-national community in the province plays an important role.

\footnotetext{
${ }^{\text {A.1 }}$ Note that the estimating period in this IV setting is 2009-2013, with the regressor of interest (and, consequently, the instrument) lagged by two years (i.e. from 2007 to 2011). This guarantees at least a 5-year lag between the aggregate shift and local shares components of the instrument. Note that we still used lagged regressors (and instruments) in order to avoid the obvious simultaneity problem stemming from the contemporaneous regressor of interest mechanically picking new firm creation in year $t$, thereby helping the instrument to control for 'real' endogeneity issues.

A.2 The shift-share instrument is a strong predictor of the regressor of interest, with a first-stage $F$-statistic well above conventional threshold levels (281.09). The first-stage regression coefficient of interest (i.e. the correlation between the imputed immigrant shares in a given province and the stock of immigrant entrepreneurs from a given nationality in a given industry and province) is 3.476 , and is statistically significant at the $1 \%$ level.
} 


\section{Table A.1: Endogeneity and interaction effects}

Dep. var.: Number of new immigrant entrepreneurs by industry, province, and country of origin at $t$ (log)

\begin{tabular}{|c|c|c|}
\hline Model 1: Lags at $t-1$ & & \\
\hline $\begin{array}{l}\text { Number of immigrant entrepreneurs by industry, province, and country of ori- } \\
\text { gin at } t-1(\log )\end{array}$ & $0.360^{* * *}$ & $(0.014)$ \\
\hline Numb & er of observa & is: 249,702 \\
\hline Model 2: Lags at $t-3$ & & \\
\hline $\begin{array}{l}\text { Number of immigrant entrepreneurs by industry, province, and country of ori- } \\
\text { gin at } t-3(\log )\end{array}$ & $0.345^{* * *}$ & $(0.013)$ \\
\hline Numb & er of observa & Is: 176,139 \\
\hline Model 3: Instrumental variable regression & & \\
\hline $\begin{array}{l}\text { Number of immigrant entrepreneurs by industry, province, and country of ori- } \\
\text { gin at } t-2(\log )\end{array}$ & $0.324^{* * *}$ & $(0.007)$ \\
\hline Numb & er of observa & is: 113,425 \\
\hline Model 4: Interaction effect & & \\
\hline $\begin{array}{l}\text { Number of immigrant entrepreneurs by industry, province, and country of ori- } \\
\text { gin at } t-2(\log )\end{array}$ & $0.290^{* * *}$ & $(0.020)$ \\
\hline Immigration rate by province and country of origin at $t-2$ & $-28.821^{* * *}$ & $(3.334)$ \\
\hline $\begin{array}{l}\text { Number of immigrant entrepreneurs by industry, province, and country of ori- } \\
\text { gin at } t-2(\log ) * \text { Immigration rate by province and country of origin at } \\
t-2\end{array}$ & $16.672^{* * *}$ & $(2.074)$ \\
\hline
\end{tabular}

Number of observations: 210,363

Source: ASIA data set (2002-2013)

Estimation method: OLS/IV regressions. Driscoll-Kraay standard errors, robust to autocorrelation, heteroscedasticity, and cross-sectional dependence, in parentheses. ${ }^{* * *},{ }^{* *}$, and ${ }^{*}$ denote, respectively, the $1 \%$, $5 \%$, and $10 \%$ significance levels. Model 1 replicates the estimation in Specification 7 of Table 2 but with the regressor of interest and the control variables lagged by one (instead of two) periods (i.e. at $t-1$ ). Model 2 replicates the estimation in Specification 7 of Table 2 but with the regressor of interest and the control variables lagged by three (instead of two) periods (i.e. at $t-3$ ). Model 3 presents the results for instrumental variable estimation using the shift-share instrument defined in the text and based on Card (2001). The estimating time period is 2009-2013, in order to have at least a 5-year lag between the local shares at $t^{0}$ (i.e. 2002) and the aggregate shifts components on which the instrument is constructed (see the text). Controls in this specification are the number of entrepreneurs by industry and province at $t-2$ as defined in Table 2, year dummies, industry dummies, country of origin dummies, year*industry dummies, and year*country of origin dummies. Year*province dummies are excluded since they are collinear with the instrument. Province dummies are excluded to improve the power of the instrument, which varies at the provincial/annual level. Model 4 takes into accounts possible interaction effects between the regressor of interest and the immigration rate by province and country of origin. It includes the same set of controls as Specification 7 in Table 2. 


\section{B. Robustness II: Alternative proxies for the degree of gender inequality in the destination}

\section{Table B.1: Province of destination - women city councilors}

\begin{tabular}{|c|c|c|c|}
\hline & Males & Females & $\begin{array}{l}\text { Gender dif- } \\
\text { ference }\end{array}$ \\
\hline & $\begin{array}{l}\text { Dep. var.: Number of } \\
\text { new male immigrant en- } \\
\text { trepreneurs by industry, } \\
\text { province, and country of } \\
\text { origin at } t \text { (log) }\end{array}$ & $\begin{array}{l}\text { Dep. var.: Number of } \\
\text { new female immigrant en- } \\
\text { trepreneurs by industry, } \\
\text { province, and country of } \\
\text { origin at } t \text { (log) }\end{array}$ & \\
\hline \multicolumn{4}{|c|}{ Gender differences by percentage of women city councilors in the province of destinatior } \\
\hline \multicolumn{4}{|c|}{ Provinces of destination with high percentages of women city councilors } \\
\hline $\begin{array}{l}\text { Number of immigrant en- } \\
\text { trepreneurs by industry, } \\
\text { province, and country of } \\
\text { origin at } t-2(\log )\end{array}$ & $0.321^{* * *} \quad(0.014)$ & $0.178^{* * *} \quad(0.004)$ & $-0.142^{* * *}$ \\
\hline Number of observations & 113,458 & 75,922 & \\
\hline \multicolumn{4}{|c|}{ Provinces of destination with low percentages of women city councilors } \\
\hline $\begin{array}{l}\text { Number of immigrant en- } \\
\text { trepreneurs by industry, } \\
\text { province, and country of } \\
\text { origin at } t-2(\log )\end{array}$ & $0.284^{* * *} \quad(0.020)$ & $0.162^{* * *} \quad(0.011)$ & $-0.122^{* * *}$ \\
\hline Number of observations & 96,905 & 63,189 & \\
\hline
\end{tabular}

Source: ASIA data set (2002-2013)

Estimation method: OLS. Driscoll-Kraay standard errors, robust to autocorrelation, heteroscedasticity, and cross-sectional dependence, in parentheses. ${ }^{* * *},{ }^{* *}$, and ${ }^{*}$ denote, respectively, the $1 \%, 5 \%$, and $10 \%$ significance levels. All regressions include the same set of controls as Specification 7 of Table 2. The number of women city councilors (and total city councilors) in each municipality and year are provided by ISTAT. We aggregate this information at the provincial level and compute, for each province and year, the percentage of women city councilors in the province of destination as the ratio of the total number of women city councilors to the total number of city councilors in that province and year. Provinces of destination with low (high) percentages of women city councilors are defined as those below (above) the median. 
Table B.2: Province of destination - women mayors

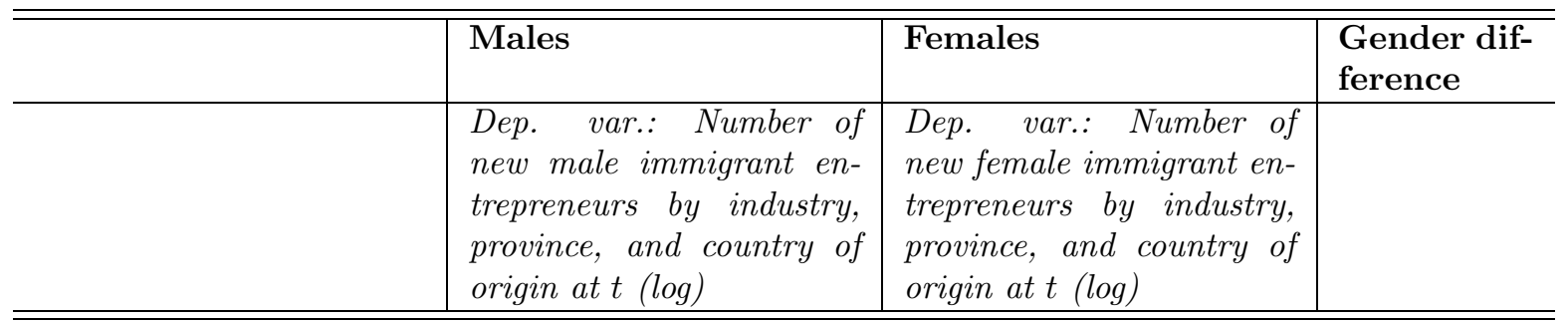

Gender differences by presence of woman mayors in the province of destination Provinces of destination with high presence of women mayors

\begin{tabular}{l|l|l|l|l}
\hline $\begin{array}{l}\text { Number of immigrant en- } \\
\text { trepreneurs by industry, } \\
\text { province, and country of } \\
\text { origin at } t-2(\log )\end{array}$ & $0.333^{* * *}(0.019)$ & $0.181^{* * *} \quad(0.006)$ & $-0.152^{* * *}$ \\
\hline Number of observations & 112,115 & 73,718 & \\
\hline \multicolumn{4}{c}{ Provinces of destination with low presence of woman mayors } \\
\hline $\begin{array}{l}\text { Number of immigrant en- } \\
\text { trepreneurs by industry, } \\
\text { province, and country of } \\
\text { origin at } t-2(\log )\end{array}$ & $0.266^{* * *}(0.011)$ & $0.158^{* * *}(0.009)$ & $-0.108^{* * *}$ \\
\hline Number of observations & 98,248 & & \\
\hline
\end{tabular}

Source: ASIA data set (2002-2013)

Estimation method: OLS. Driscoll-Kraay standard errors, robust to autocorrelation, heteroscedasticity, and cross-sectional dependence, in parentheses. ${ }^{* * *},{ }^{* *}$, and ${ }^{*}$ denote, respectively, the $1 \%, 5 \%$, and $10 \%$ significance levels. All regressions include the same set of controls as Specification 7 of Table 2. The gender of the mayor in each municipality and year is provided by ISTAT. We aggregate this information at the provincial level and compute, for each province and year, the presence of women mayors in the province of destination as the ratio between the number of municipalities with women mayors and the total number of municipalities in that province and year. Provinces of destination with low (high) presence of women mayors are defined as those below (above) the median. 
Table B.3: Province of destination - native women entrepreneurs

\begin{tabular}{l|l|l|l}
\hline \hline & Males & Females & $\begin{array}{l}\text { Gender dif- } \\
\text { ference }\end{array}$ \\
\hline & $\begin{array}{l}\text { Dep. var.: Number of } \\
\text { new male immigrant en- }\end{array}$ & $\begin{array}{l}\text { Dep. var.: Number of } \\
\text { new female immigrant en- }\end{array}$ & \\
& $\begin{array}{l}\text { trepreneurs by industry, } \\
\text { province, and country of } \\
\text { origin at } t \text { (log) }\end{array}$ & $\begin{array}{l}\text { province, and country of } \\
\text { origin at } t \text { (log) }\end{array}$ & \\
\hline \hline
\end{tabular}

$\overline{\text { Gender differences by percentages of native women entrepreneurs in the province of destination }}$ Provinces of destination with high percentages of native women entrepreneurs

\begin{tabular}{l|l|l|l|l}
\hline $\begin{array}{l}\text { Number of immigrant en- } \\
\text { trepreneurs by industry, } \\
\text { province, and country of } \\
\text { origin at } t-2 \text { (log) }\end{array}$ & $0.293^{* * *}(0.011)$ & $0.173^{* * *}(0.007)$ & $-0.120^{* * *}$ \\
\hline Number of observations & 112,650 & 79,597 & $-0.150^{* * *}$ \\
\hline \multicolumn{4}{c}{ Provinces of destination with low percentages of native women entrepreneurs } \\
\hline $\begin{array}{l}\text { Number of immigrant en- } \\
\text { trepreneurs by industry, } \\
\text { province, and country of } \\
\text { origin at } t-2 \text { (log) }\end{array}$ & $0.314^{* * *}(0.016)$ & $0.164^{* * *}(0.005)$ & \\
\hline Number of observations & 97,713 & 59,514 & \\
\hline
\end{tabular}

Source: ASIA data set (2002-2013)

Estimation method: OLS. Driscoll-Kraay standard errors, robust to autocorrelation, heteroscedasticity, and crosssectional dependence, in parentheses. $* * *, * *$, and $*$ denote, respectively, the $1 \%, 5 \%$, and $10 \%$ significance levels. All regressions include the same set of controls as Specification 7 of Table 2. Using the ASIA data set, we compute, for each province and year, the percentage of native women entrepreneurs in the province of destination as the ratio between the total number of native women entrepreneurs and the total number of native entrepreneurs in that province and year. Provinces of destination with low (high) percentages of native women entrepreneurs are defined as those below (above) the median. 
Table B.4: Province of destination - combination of the three proxies (women city councilors, women mayors, native women entrepreneurs)

\begin{tabular}{|c|c|c|c|}
\hline & Males & Females & $\begin{array}{l}\text { Gender dif- } \\
\text { ference }\end{array}$ \\
\hline & $\begin{array}{l}\text { Dep. var.: Number of } \\
\text { new male immigrant en- } \\
\text { trepreneurs by industry, } \\
\text { province, and country of } \\
\text { origin at } t(\mathrm{log})\end{array}$ & $\begin{array}{l}\text { Dep. var.: Number of } \\
\text { new female immigrant en- } \\
\text { trepreneurs by industry, } \\
\text { province, and country of } \\
\text { origin at } t \text { (log) }\end{array}$ & \\
\hline \multicolumn{4}{|c|}{ Gender differences by combination of the three proxies in the province of destination } \\
\hline \multicolumn{4}{|c|}{$\begin{array}{l}\text { Provinces of destination with high percentages of women city councilors and high } \\
\text { presence of women mayors and high percentages of native women entrepreneurs }\end{array}$} \\
\hline $\begin{array}{l}\text { Number of immigrant en- } \\
\text { trepreneurs by industry, } \\
\text { province, and country of } \\
\text { origin at } t-2(\log )\end{array}$ & $0.328^{* * *} \quad(0.010)$ & $0.180^{* * *} \quad(0.006)$ & $-0.148^{* * *}$ \\
\hline Number of observations & 47,332 & 33,947 & \\
\hline \multicolumn{4}{|c|}{$\begin{array}{l}\text { Provinces of destination with low percentages of women city councilors and low } \\
\text { presence of women mayors and low percentages of native women entrepreneurs }\end{array}$} \\
\hline $\begin{array}{l}\text { Number of immigrant en- } \\
\text { trepreneurs by industry, } \\
\text { province, and country of } \\
\text { origin at } t-2(\log )\end{array}$ & $0.295^{* * *} \quad(0.013)$ & $0.156^{* * *} \quad(0.007)$ & $-0.139^{* * *}$ \\
\hline Number of observations & 28,484 & 17,402 & \\
\hline
\end{tabular}

Source: ASIA data set (2002-2013)

Estimation method: OLS. Driscoll-Kraay standard errors, robust to autocorrelation, heteroscedasticity, and cross-sectional dependence, in parentheses. ${ }^{* * *}, * *$, and $*$ denote, respectively, the $1 \%, 5 \%$, and $10 \%$ significance levels. All regressions include the same set of controls as Specification 7 of Table 2. The three proxies for the degree of gender inequality in the province of destination (high/low percentages of women city councilors, presence of women mayors, and percentages of native women entrepreneurs) are defined as in Tables B.1, B.2, and B.3, respectively. Note that here we rely on the intersection of the three proxies to identify provinces characterized by low and high gender inequality. 
Table B.5: Country of origin versus province of destination

\begin{tabular}{l|l|l|l}
\hline \hline & Males & Females & $\begin{array}{l}\text { Gender dif- } \\
\text { ference }\end{array}$ \\
\hline & $\begin{array}{l}\text { Dep. var. Number of } \\
\text { new male immigrant en- }\end{array}$ & $\begin{array}{l}\text { Dep. var.: Number of } \\
\text { newale immigrant en- }\end{array}$ & \\
& $\begin{array}{l}\text { trepreneurs by industry, } \\
\text { province, and country of } \\
\text { origin att (log) }\end{array}$ & $\begin{array}{l}\text { province, and country of } \\
\text { origin at t (log) }\end{array}$ & \\
\hline \hline
\end{tabular}

\section{Gender differences by GIIs in the country of origin and combination of the three proxies in the province of destination}

Countries of origin with low GIIs and provinces of destination with high percentages of women city councilors and high presence of women mayors and high percentages of native women entrepreneurs

\begin{tabular}{|c|c|c|c|}
\hline $\begin{array}{l}\text { Number of immigrant en- } \\
\text { trepreneurs by industry, } \\
\text { province, and country of } \\
\text { origin at } t-2(\log )\end{array}$ & $0.218^{* * *} \quad(0.009)$ & $0.219^{* * *} \quad(0.009)$ & +0.001 \\
\hline Number of observations & 17,460 & 15,012 & \\
\hline \multicolumn{4}{|c|}{$\begin{array}{l}\text { Countries of origin with low GIIs and provinces of destination with low percentages of women city } \\
\text { councilors and low presence of women mayors and low percentages of native women entrepreneurs }\end{array}$} \\
\hline $\begin{array}{l}\text { Number of immigrant en- } \\
\text { trepreneurs by industry, } \\
\text { province, and country of } \\
\text { origin at } t-2(\log )\end{array}$ & $0.218^{* * *} \quad(0.007)$ & $0.202^{* * *} \quad(0.006)$ & -0.016 \\
\hline Number of observations & 14,324 & 9,932 & \\
\hline \multicolumn{4}{|c|}{$\begin{array}{l}\text { Countries of origin with high GIIs and provinces of destination with high percentages of women city } \\
\text { councilors and high presence of women mayors and high percentages of native women entrepreneurs }\end{array}$} \\
\hline $\begin{array}{l}\text { Number of immigrant en- } \\
\text { trepreneurs by industry, } \\
\text { province, and country of } \\
\text { origin at } t-2(\log )\end{array}$ & $0.387^{* * *} \quad(0.014)$ & $0.152^{* * *} \quad(0.006)$ & $-0.235^{* * *}$ \\
\hline Number of observations & 25,210 & 16,058 & \\
\hline \multicolumn{4}{|c|}{$\begin{array}{l}\text { Countries of origin with high GIIs and provinces of destination with low percentages of women city } \\
\text { councilors and low presence of women mayors and low percentages of native women entrepreneurs }\end{array}$} \\
\hline $\begin{array}{l}\text { Number of immigrant en- } \\
\text { trepreneurs by industry, } \\
\text { province, and country of } \\
\text { origin at } t-2(\log )\end{array}$ & $0.367^{* * *} \quad(0.017)$ & $0.094^{* * *} \quad(0.010)$ & $-0.273^{* * *}$ \\
\hline Number of observations & 12,149 & 6,504 & \\
\hline
\end{tabular}

Source: ASIA data set (2002-2013)

Estimation method: OLS. Driscoll-Kraay standard errors, robust to autocorrelation, heteroscedasticity, and cross-sectional dependence, in parentheses. ${ }^{* * *},{ }^{* *}$, and $*$ denote, respectively, the $1 \%, 5 \%$, and $10 \%$ significance levels. All regressions include the same set of controls as Specification 7 of Table 2. Countries of origin with low/high GIIs are defined as in Table 4. As noted in Table 4, unfortunately, GIIs for 2008 have not been reported for some (small) countries, which entails a loss of around $8 \%$ of the observations. The three proxies for the degree of gender inequality in the province of destination (high/low percentages of women city councilors, presence of women mayors, and percentages of native women entrepreneurs) are defined as in Tables B.1, B.2, and B.3, respectively. Note that, as in Table B.4, here we rely on the intersection of the three proxies to identify provinces characterized by low and high gender inequality. 